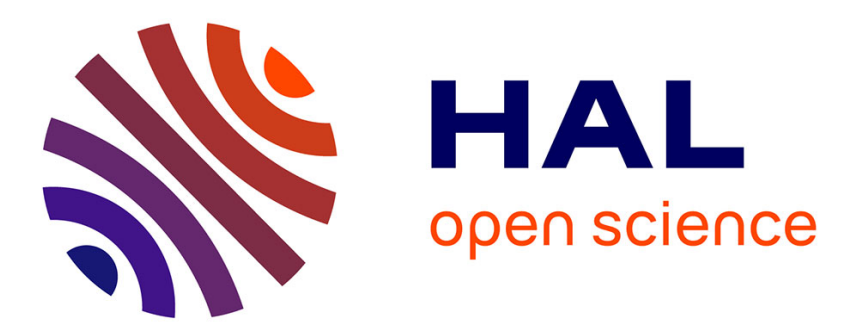

\title{
Coupled Al-Si geochemistry in an ocean general circulation model: A tool for the validation of oceanic dust deposition fields?
}

\author{
M. Gehlen, C. Heinze, E. Maier-Reimer, C.I. Measures
}

\section{- To cite this version:}

M. Gehlen, C. Heinze, E. Maier-Reimer, C.I. Measures. Coupled Al-Si geochemistry in an ocean general circulation model: A tool for the validation of oceanic dust deposition fields?. Global Biogeochemical Cycles, 2003, 17 (1), 10.1029/2001GB001549 . hal-03113028

\author{
HAL Id: hal-03113028 \\ https://hal.science/hal-03113028
}

Submitted on 18 Jan 2021

HAL is a multi-disciplinary open access archive for the deposit and dissemination of scientific research documents, whether they are published or not. The documents may come from teaching and research institutions in France or abroad, or from public or private research centers.
L'archive ouverte pluridisciplinaire HAL, est destinée au dépôt et à la diffusion de documents scientifiques de niveau recherche, publiés ou non, émanant des établissements d'enseignement et de recherche français ou étrangers, des laboratoires publics ou privés. 


\title{
Coupled Al-Si geochemistry in an ocean general circulation model: A tool for the validation of oceanic dust deposition fields?
}

\author{
M. Gehlen \\ Laboratoire des Sciences du Climat et de l'Environnement (LSCE), UMR CEA-CNRS, Gif-sur-Yvette, France \\ C. Heinze ${ }^{1}$ and E. Maier-Reimer \\ Department of Atmospheric Chemistry and Climate Dynamics, Max Planck Institut of Meteorology, Hamburg, Germany \\ C. I. Measures \\ Department of Oceanography, University of Hawaii, Honolulu, Hawaii, USA
}

Received 22 August 2001; revised 26 June 2002; accepted 29 August 2002; published 19 March 2003.

[1] We introduced the marine cycle of Al into a geochemical ocean general circulation model in order to assess the potential of modeled surface ocean dissolved $\mathrm{Al}$ as a tracer for dust input to the world ocean. The geochemical cycles of Si and Al have been coupled through the dynamics of diatoms. Aluminum is added to the ocean by deposition of continental aerosols followed by partial dissolution of the aluminosilicate fraction. Dissolved Al interacts with suspended siliceous particles according to a reversible first-order scavenging reaction. Dust fields are provided by Atmospheric General Circulation Models. A database of marine dissolved Al measurements was collated. The ocean model results for two different dust deposition fields [Andersen et al., 1998; Mahowald et al., 1999] are compared with these data. The model confirms a solubility of the aluminosilicate fraction between 1.5 and $3.0 \%$. Modeled levels of dissolved Al in surface waters mirror the delivery of dust to the surface ocean. Comparing dissolved $\mathrm{Al}$ distributions resulting from the two different dust fields, yields significant differences in ocean dissolved Al distributions, which reflect a differential contribution of individual source regions. Model results suggest a significant overestimation of the North African-Arabian desert source region for the dust field after Mahowald et al. [1999]; dust input to the central Pacific Ocean appears to be of the correct order of magnitude. This approach allows for a direct comparison of dust fields and proposes an independent check of the underlying parameterization of uplift, transport and deposition of dust. INDEX TERMS: 4801 Oceanography: Biological and Chemical: Aerosols (0305); 4805 Oceanography: Biological and Chemical: Biogeochemical cycles (1615); 4808 Oceanography: Biological and Chemical: Chemical tracers; KEYWORDS: marine biogeochemical cycles, Al, $\mathrm{Si}$, continental aerosols, global modeling

Citation: Gehlen, M., C. Heinze, E. Maier-Reimer, and C. I. Measures, Coupled Al-Si geochemistry in an ocean general circulation model: A tool for the validation of oceanic dust deposition fields?, Global Biogeochem. Cycles, 17(1), 1028, doi:10.1029/ 2001GB001549, 2003.

\section{Introduction}

[2] Records of ice core and marine sediments indicate important changes of dust deposition rates between glacial and interglacial periods [e.g., De Angelis et al., 1987; Petit et al., 1990; Jouzel et al., 1993; Rea, 1994; Broecker and Henderson, 1998], suggesting a role of the dust cycle in

\footnotetext{
${ }^{1}$ Now at National Environmental Research Institute (NERI), Roskilde, Denmark.

Copyright 2003 by the American Geophysical Union. 0886-6236/03/2001GB001549
}

global climate dynamics. Whether the observed changes in dust accumulation are a driving force or merely a consequence of switching between climate modes remains, however, an open question. From the point of view of ocean chemistry, aerosols of continental origin represent an important source of trace elements to open ocean waters. While the effect of partial dissolution of dust on ocean biogeochemistry remains largely unknown, several trace elements are essential components of coenzymes (e.g. $\mathrm{Zn}, \mathrm{Co}, \mathrm{Cu}$ ). Among the dust-born trace elements of potential biological importance, Fe might act as a limiting micronutrient for primary production in high-nitrate low-chlorophyll (HNLC) areas of the world ocean [Martin and Fitzwater, 1988]. An 
improved quantification of dust input to the world ocean appears as an important first step in furthering our understanding of the role of dust deposition on modern ocean fertility and its potential feedback on the climate system.

[3] The ocean might be seen as a dust collector [Measures and Brown, 1996] integrating atmospheric continental aerosol input over time, while smoothing high-frequency signals due to the episodic nature of deposition events. Surface ocean dissolved Al concentrations have been proposed as a proxy for dust deposition [Measures and Brown, 1996; Measures and Vink, 2000]. The potential of $\mathrm{Al}$ as a tracer for dust input is directly linked to its geochemical characteristics namely its eolian source, its short residence time in surface waters and, in comparison to $\mathrm{Fe}$ for instance, simplified chemistry (no redox chemistry). Its open ocean distribution is controlled by external input, via the partial dissolution of eolian dust, and rapid removal from the water column by scavenging to particles.

[4] Following an inverse approach, Measures and Brown [1996] and Measures and Vink [2000] presented a model allowing to estimate dust input from observed surface water dissolved Al concentrations. Their approach implicitly assumes surface ocean dissolved $\mathrm{Al}$ levels to be in steady state. At any particular location, the dissolved Al concentration will reflect a balance between input fluxes from dust deposition and losses by scavenging to particles. The model ignores the effect of advection of water masses, a shortcoming acknowledged by Measures and Brown [1996] and Measures and Vink [2000]. In order to derive dust deposition rates from dissolved $\mathrm{Al}$ concentrations, knowledge of the residence time and mixed layer depth is needed. The authors used a uniform residence time for all investigated locations within the Atlantic and the Pacific Ocean. The residence timescales however with primary productivity [Orians and Bruland, 1986; van Beusekom, 1988; Measures and Brown, 1996] and is not uniform over large oceanic areas. In a similar manner, the use of a single mixed layer depth results in over- or underestimations of dust input depending on a shallower or deeper mixed layer depth.

[5] These shortcomings are overcome by the use of a biogeochemical ocean general circulation model. The latter has the advantage of including the effect of advection of water masses on the distribution of dissolved Al. Further, no a priori knowledge on dissolved $\mathrm{Al}$ residence time or mixed layer depth is needed. While the latter is computed by the general circulation model, the former results from the calculated steady state distribution of dissolved $\mathrm{Al}$ including the effect of regionally variable primary production.

[6] We introduced the marine cycle of Al into a welldocumented biogeochemical ocean general circulation model (the Hamburg Oceanic Carbon Cycle Model [Heinze et al., 1991; Maier-Reimer, 1993; Heinze et al., 1999]). As biogenic siliceous particles appear to be the main carrier phase for scavenged Al [Stoffyn, 1979; Moran and Moore, 1988; Dymond et al., 1997], the geochemical cycles of Si and $\mathrm{Al}$ are coupled through the dynamics of diatoms. The input of mineral aerosols to the surface ocean is provided by dust fields computed by atmospheric general circulation models (AGCM). This approach allows for a direct comparison of dust fields (for this study see Andersen et al. [1998] and Mahowald et al. [1999]) and proposes an independent check of the underlying parameterization of uplift, transport and deposition of dust. In this study, we will address the suitability of our approach as a tool for the validation of dust input to the modern ocean.

\section{Marine Chemistry of Al}

[7] Aluminum is the third most common element in terms of crustal abundance (8.2\% [Taylor, 1964; Wedepohl, 1995]) and its geochemical cycle is a longstanding interest of marine geochemistry [e.g., Mackenzie and Garrels, 1966; Hydes, 1979; Mackenzie et al., 1978; Orians and Bruland, 1985; Measures et al., 1986; Hydes, 1989; Measures and Edmond, 1990; Chou and Wollast, 1997]. Dissolved Al concentrations have been used in the past as a tracer of water masses [Measures and Edmond, 1988, 1992], and more recently as a proxy for dust deposition [Measures and Brown, 1996; Measures and Vink, 2000].

[8] The predominant source of $\mathrm{Al}$ to open ocean surface waters is the partial dissolution of the aluminosilicate fraction of eolian continental dust. Dissolved Al provided to the world ocean by riverine input is largely sequestered in estuarine and coastal sediments [Maring and Duce, 1987]. While the average $\mathrm{Al}$ content of eolian dust reflects the mean crustal abundance, there are still large uncertainties concerning its solubility. Estimates of dust solubility range from 1.5 up to 10\% [e.g. Maring and Duce, 1987; Prospero et al., 1987; Chester et al., 1993]. Contrasting with the generally assumed low reactivity of aluminosilicate minerals, laboratory experiments suggest a rapid release of $\mathrm{Al}$ to seawater, with up to $10 \%$ of Al from aerosols of crustal origin dissolving within 60 hr [Maring and Duce, 1987]. The solubility of Al increases with decreasing $\mathrm{pH}$ and about $5 \%$ of dust derived aluminosilicate Al appears to be soluble in rain [Prospero et al., 1987]. A further unknown fraction of $\mathrm{Al}$ might be released to oceanic waters upon exposure to low-pH environments following the ingestion of particles by plankton organisms.

[9] The vertical distribution of Al typically exhibits a surface maximum, followed by a minimum at mid-depth and a slight increase toward the sediment-water interface. Dissolved Al levels decrease from the North Atlantic to North Pacific. Both, vertical distribution and between ocean basin fractionation suggest the distribution of $\mathrm{Al}$ to be controlled by scavenging [ $L i, 1991]$. Aluminum is a very particle reactive element (dominant speciation as $\mathrm{Al}(\mathrm{OH})_{4}{ }^{-}$ according to Turner et al. [1981]) and has been compared to thorium in past studies [Moran and Moore, 1989, 1992]. Obviously both elements differ with respect to sources, radioactive decay for ${ }^{230} \mathrm{Th}$, and scavenging behavior. While there is no unambiguous evidence for preferential scavenging of ${ }^{230} \mathrm{Th}$ on different types of particles (biogenic opal, $\mathrm{CaCO}_{3}$, POC, Fe-Mn oxyhydroxides, and terrigenous), $\mathrm{Al}$ has a strong affinity for biogenic siliceous debris. The assumption of preferential scavenging of $\mathrm{Al}$ by diatoms is suggested by two lines of evidence. First, the observation that reduced levels of dissolved $\mathrm{Al}$ are associated with high diatom productivity [Orians and Bruland, 1986; van Beusekom, 1988]. Second, the positive correlation between $\mathrm{Al}$ associated with biogenic carrier phases (Al-excess) and the biogenic opal concentration of settling particles reported for 
samples of the equatorial Pacific. Adding up to this evidence, there is an inverse correlation between Al-excess and $\mathrm{CaCO}_{3}$, and a lack of correlation between organic $\mathrm{C}$ and $\mathrm{Al}-$ excess [Dymond et al., 1997]. While there has been some debate in the past whether $\mathrm{Al}$ is adsorbed to the soft tissue of diatoms [Moran and Moore, 1988] or incorporated in the opal skeleton [Stoffyn, 1979], a recent study demonstrated the structural relationship between $\mathrm{Al}$ and biogenic opal [Gehlen et al., 2002].

[10] Finally, the particle reactive behavior of $\mathrm{Al}$ explains its low background concentration in open ocean waters outside of areas of significant dust input $( \pm 1 \mathrm{n} M)$ and is short residence time (several weeks to 6.5 years) in the surface ocean [Orians and Bruland, 1986; Maring and Duce, 1987; Jickells et al., 1994].

\section{Dust Input to the Open Ocean}

[11] The deposition of mineral aerosols to the ocean is poorly quantified. Direct measurements of dust deposition to open ocean surface waters are sparse. Duce et al. [1991] compiled existing observations to produce global maps of aerosol deposition to the ocean. Their model combines measured dust concentration in the marine boundary layer and extrapolations of these data into adjacent regions with dry deposition velocities, precipitation scavenging ratios and precipitation fields to evaluate mean yearly atmospheric fluxes at a resolution of $10^{\circ} \times 10^{\circ}$. The interested reader might refer to Duce et al. [1991] for a detailed model presentation. Highest mineral aerosol fluxes are found in the tropical North Atlantic with a maximum exceeding 27.4 $\mathrm{g} / \mathrm{m}^{-2} / \mathrm{d}$. They are associated with long-range transport of Saharan dust. Fluxes of the same order of magnitude are reported off the eastern shore of Asia. They are related to the central Asian source region. Dust deposition decreases moving toward the central Pacific. Fluxes below 0.03 $\mathrm{g} / \mathrm{m}^{-2} / \mathrm{d}$ are estimated for most of the Southern Ocean and the southeastern Pacific.

[12] Alternatively, deposition of mineral aerosols to the surface ocean can be estimated from Atmospheric General Circulation models (AGCM). This approach relies on parameterizations of uplift, transport and deposition of mineral aerosols. We selected two dust fields for this study by Andersen et al. [1998] (Figure 1a) and Mahowald et al. [1999] (Figure 1b), which rely on different parameterizations. For example, dust source regions are either simulated using a coupled biogeography/biogeochemistry model [Mahowald et al., 1999] or prescribed from a vegetation database [Andersen et al., 1998]. In addition to important differences in process parameterizations, both fields differ with respect to the total amount of yearly dust production. Following Duce [1994], a present-day global annual dust production of $2000 \mathrm{Mt} / \mathrm{yr}$ was prescribed by Andersen et al. [1998], as compared to $3000 \mathrm{Mt} / \mathrm{yr}$ by Mahowald et al. [1999]. In both cases, global dust emissions fall within the range of proposed values, varying from 200 up to $5000 \mathrm{Mt} /$ yr [Marticorena and Bergametti, 1995; Tegen and Fung, 1994]. The resulting simulated dust deposition fields (Figure 1) differ with respect to peak input regions and magnitude of deposition. Mahowald et al. [1999] predicts, for example, a greater source strength for the northern African and Arabian deserts, while Andersen et al. [1998] suggest larger dust emissions from Chinese and Australian deserts.

\section{Model Description}

[13] We selected the Hamburg Ocean Carbon Cycle Model (HAMOCC2 [Maier-Reimer, 1993]) in its annually averaged version including interactive sediment for this study. Ocean circulation is provided by the annual mean flow field from the well-documented dynamical Large Scale Geostrophic Ocean General Circulation Model (LSGOGCM [Maier-Reimer et al., 1993]). The model velocity field used in this study shows quantitatively realistic patterns for horizontal as well as vertical components [Winguth et al., 1999]. This is corroborated by appropriate simulations of the water column distributions of dissolved phosphate, carbonate ion, $\delta^{13} \mathrm{C}$ of DIC, $\delta^{14} \mathrm{C}$ of $\mathrm{DIC}, \mathrm{Si}(\mathrm{OH})_{4}$ and related tracers which have been carried out on the basis of this flow field [Winguth et al., 1999; Winguth, 1997; Heinze and Maier-Reimer, 1999; Heinze, 2002; C. Heinze et al., Sensitivity of the marine "biospheric" Si cycle for biogeochemical parameter variations, submitted to Global Biogeochemical Cycles, 2002 (hereinafter referred to as Heinze et al., submitted manuscript, 2002)].

[14] The velocity fields are taken off line and used to force the Hamburg Ocean Carbon Cycle Model (HAMOCC2). It has a horizontal resolution of $3.5^{\circ}$ degrees. In the vertical, the model is composed of 11 layers in the water column and 10 layers in the bioturbated sediment. The model includes four different kinds of particles: POC, $\mathrm{CaCO}_{3}$, biogenic opal and mineral aerosols. Biological production is limited by the availability of phosphate in the case of POC and silicic acid for diatom growth. POC and opal production are computed implicitly within the advection algorithm. Nutrient uptake follows MichaelisMenten kinetics [e.g., Parsons and Takahashi, 1973]:

$$
\begin{gathered}
\mathrm{P}_{\mathrm{POC}}=\alpha\left(\frac{\mathrm{V}_{\max }^{\mathrm{POC}}\left[\mathrm{PO}_{4}^{3-}\right]^{2}}{\mathrm{~K}_{\mathrm{s}}^{\mathrm{POC}}+\left[\mathrm{PO}_{4}^{3-}\right]}\right) \\
\mathrm{P}_{\mathrm{opal}}=\alpha\left(\frac{\mathrm{V}_{\max }^{\mathrm{opal}}\left[\mathrm{Si}(\mathrm{OH})_{4}\right]^{2}}{\mathrm{~K}_{\mathrm{s}}^{\mathrm{opal}}+\left[\mathrm{Si}(\mathrm{OH})_{4}\right]}\right)
\end{gathered}
$$

where

$\mathrm{P}_{\mathrm{POC}}=$ POC production $\left(\mathrm{mol} / \mathrm{dm}^{3} / \mathrm{yr}\right) ;$

$\alpha \quad$ parameter for physical growth conditions;

$\mathrm{V}_{\max }^{\mathrm{POC}} \quad$ maximum uptake rate of phosphate $(1 / \mathrm{yr})$;

$\mathrm{K}_{\mathrm{s}}^{\text {POC }}$ half saturation constant for POC production (mol/ $\left.\mathrm{dm}^{3}\right)$;

$\mathrm{P}_{\text {opal }} \quad$ opal production $\left(\mathrm{mol} / \mathrm{dm}^{3} / \mathrm{yr}\right)$;

$\mathrm{V}_{\max }^{\text {opal }}$ maximum uptake rate of silicic acid (1/yr);

$\mathrm{K}_{\mathrm{s}}^{\text {opal }}$ half saturation constant for opal production (mol/ $\left.\mathrm{dm}^{3}\right)$.

The production of $\mathrm{CaCO}_{3}$ is derived from the ratio of opal to $\mathrm{POC}$ production rates:

$$
\mathrm{P}_{\mathrm{CaCO} 3}=\mathrm{P}_{\mathrm{POC}} \mathrm{r}\left(1-\frac{\mathrm{P}_{\mathrm{opal}}}{\mathrm{P}_{\mathrm{POC}}} / \mathrm{S}_{\mathrm{opal}}\right)
$$


(a) dust deposition [mg/(m2 day)]

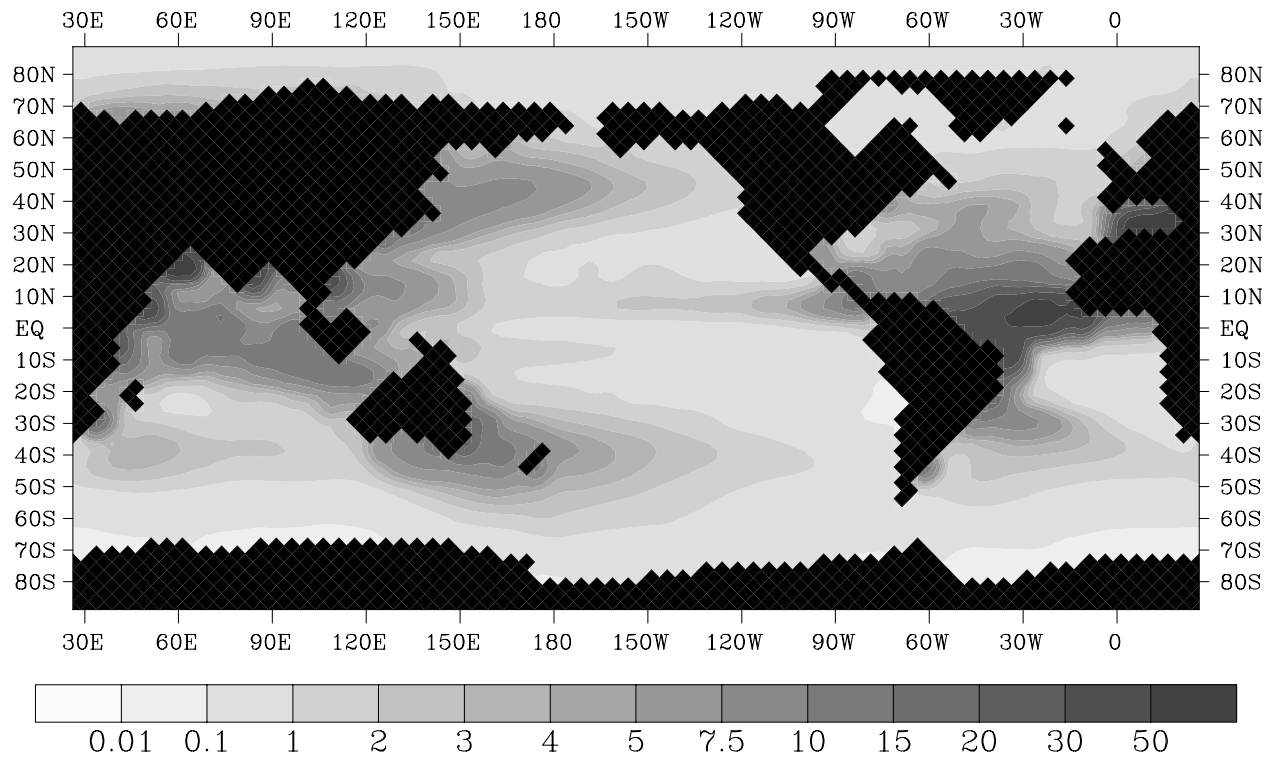

(b) dust deposition [mg/(m2 day)]

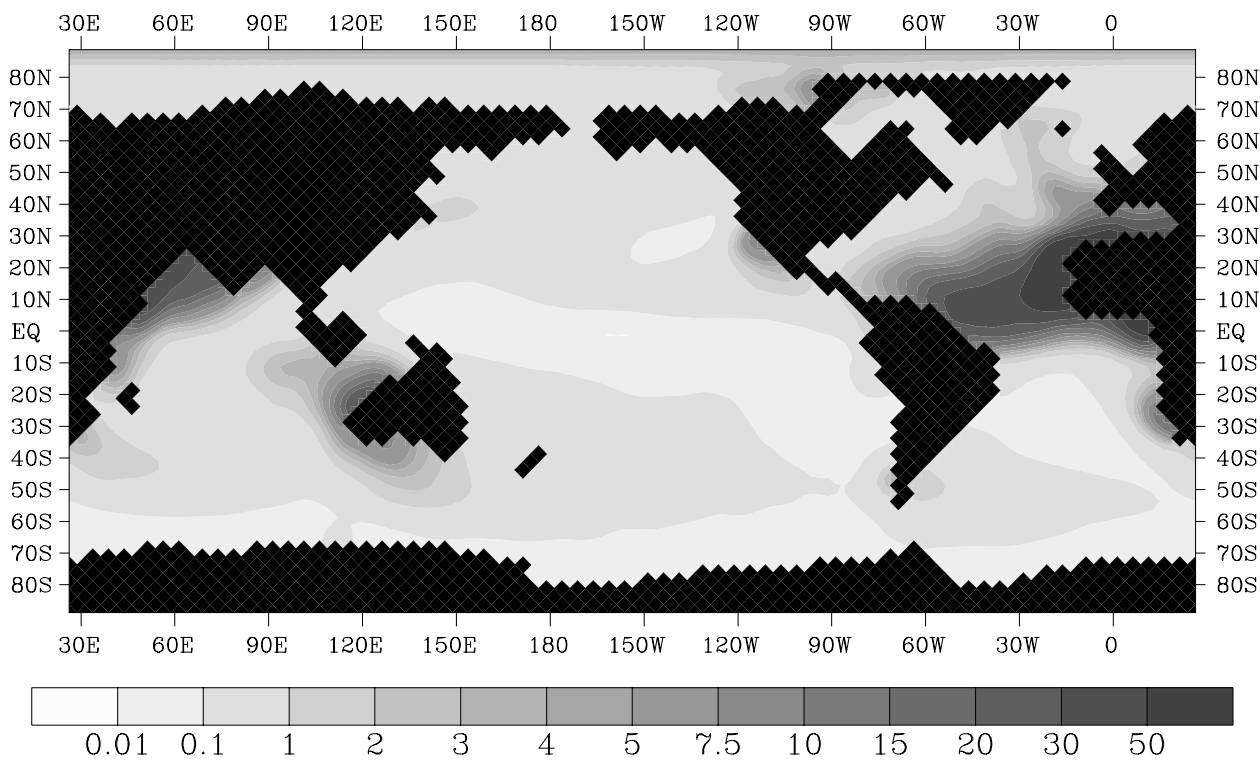

Figure 1. Annually averaged dust deposition ( $\mathrm{mg} / \mathrm{m}^{2} / \mathrm{d}$ ) after (a) Andersen et al. [1998] and (b) Mahowald et al. [1990]. See color version of this figure at back of this issue.

with

$$
\frac{\mathrm{P}_{\text {opal }}}{\mathrm{P}_{\mathrm{POC}}}<\mathrm{S}_{\mathrm{opal}}
$$

where

$\mathrm{P}_{\mathrm{CaCO} 3}=\mathrm{CaCO}_{3}$ production $\left(\mathrm{mol} / \mathrm{dm}^{3} / \mathrm{yr}\right)$;

$\mathrm{r} \quad$ fitting parameter;

$\mathrm{S}_{\text {opal }} \quad$ threshold value.

[15] Parameter values are summarized in Table 1. Biogenic production is limited to the uppermost $50 \mathrm{~m}$ of the water column. The flux of biogenic particles is described by specifying sinking velocities, $\mathrm{CaCO}_{3}$ and opal dissolution rates and a remineralization rate of POC (Heinze et al., submitted manuscript, 2002). Production rates are export production figures and all particles formed in the surface layer settle to the layer below. For the subsequent layers, fluxes are corrected for particle dissolution.

[16] Aluminum is added to the ocean by dust deposition and partial dissolution of the alumino-silicate fraction. The release of $\mathrm{Al}$ from dust particles is limited to the uppermost model layer $(50 \mathrm{~m})$. Dissolved Al interacts with suspended siliceous particles in the water column according the a reversible first-order scavenging reaction:

$$
\frac{\mathrm{dAl} l_{\mathrm{PART}}}{\mathrm{dt}}=\kappa\left(\mathrm{Al}_{\mathrm{PART}}^{\mathrm{EQ}}-\mathrm{Al}_{\mathrm{PART}}\right)
$$


Table 1. Model Parameters as Used in the Standard Run

\begin{tabular}{|c|c|}
\hline Tunable Model Parameter & Values \\
\hline Threshold value of particle export production $\left(\mathrm{P}_{\mathrm{opal}} / \mathrm{P}_{\mathrm{POC}}\right)$ & 0.7 \\
\hline Rain ratio $\mathrm{C}\left(\mathrm{CaCO}_{3}\right) / \mathrm{C}(\mathrm{POC})$ & 0.26 \\
\hline Global weathering input of $\mathrm{Si}$ & $5.510^{12} \mathrm{~mol} \mathrm{Si} \mathrm{yr}^{-1}$ \\
\hline Global weathering input of $\mathrm{CaCO}_{3}$ & $1510^{12} \mathrm{~mol} \mathrm{C} \mathrm{yr}^{-1}$ \\
\hline Global weathering input of $\mathrm{POC}$ & $4.010^{12} \mathrm{~mol} \mathrm{C} \mathrm{yr}^{-1}$ \\
\hline POC settling velocities (layer 1 to 11 ) & $\begin{array}{c}3.00,2.66,2.60,2.50,2.37,2.22, \\
1.93,1.60,1.38,1.23,1.08 \mathrm{~m} \mathrm{~d}^{-1}\end{array}$ \\
\hline $\mathrm{CaCO}_{3}$ settling velocities (layer 1 to 11 ) & $\begin{array}{l}3.00,2.68,2.66,2.63,2.58,2.51 \\
2.38,2.19,2.02,1.88,1.70 \mathrm{~m} \mathrm{~d}^{-1}\end{array}$ \\
\hline Opal settling velocities (layer 1 to 11 ) & $\begin{array}{l}3.00,2.70,2.69,2.69,2.67,2.66 \\
2.63,2.58,2.54,2.49,2.43 \mathrm{~m} \mathrm{~d}^{-1}\end{array}$ \\
\hline $\mathrm{CaCO}_{3}$ redissolution rate constant, water column & $0.5 \mathrm{yr}^{-1}$ \\
\hline Opal redissolution rate constant, water column & $0.1 \mathrm{yr}^{-1}$ \\
\hline POC remineralization rate constant, water column & $1.4 \mathrm{yr}^{-1}$ \\
\hline DOC remineralization rate constant, water column & $0.05 \mathrm{yr}^{-1}$ \\
\hline Solubility of aluminosilicate fraction & $3 \%$ \\
\hline Al scavenging order rate constant & $10,000 \mathrm{yr}^{-1}$ \\
\hline Partition coefficient for Al scavenging & $10^{6} \mathrm{~kg}^{-1}$ \\
\hline $\mathrm{Si}(\mathrm{OH})_{4}$ saturation concentration & $800 \mu \mathrm{mol}$ \\
\hline $\mathrm{CaCO}_{3}$ redissolution rate constant, sediment & $1000 \mathrm{lyr}^{-1} \mathrm{~mol}^{-1}$ \\
\hline Opal redissolution rate constant, sediment & $401 \mathrm{yr}^{-1} \mathrm{~mol}^{-1}$ \\
\hline POC remineralization rate constant, sediment & $501 \mathrm{yr}^{-1} \mathrm{~mol}^{-1}$ \\
\hline Diffusion coefficient, pore waters & $8.10^{6} \mathrm{~cm}^{2} \mathrm{~s}^{-1}$ \\
\hline Bioturbation coefficient & $15 \mathrm{~cm}^{2} 1000 \mathrm{yr}^{-1}$ \\
\hline
\end{tabular}

$$
\mathrm{Al}_{\mathrm{PART}}^{\mathrm{EQ}}=\mathrm{k}_{\mathrm{d}} \mathrm{Al}_{\text {DISS }} \mathrm{C}_{\text {opal }}
$$

where

$\mathrm{Al}_{\mathrm{PART}}=$ concentration of particle bound $\mathrm{Al}\left(\mathrm{mol} / \mathrm{dm}^{3}\right)$; $\mathrm{Al}_{\text {DISS }} \quad$ concentration of dissolved $\mathrm{Al}\left(\mathrm{mol} / \mathrm{dm}^{3}\right)$;

$\mathrm{Al}_{\mathrm{PART}}^{\mathrm{EQ}}$ equilibrium concentration of particle bound $\mathrm{Al}$ $\left(\mathrm{mol} / \mathrm{dm}^{3}\right)$;

$\kappa \quad$ first-order rate constant $\left(\mathrm{yr}^{-1}\right)$;

$\mathrm{k}_{\mathrm{d}} \quad$ partition coefficient $(1 / \mathrm{kg})$;

$\mathrm{C}_{\text {opal }} \quad$ concentration of suspended opal particles $(\mathrm{kg} / \mathrm{l})$

The equilibrium concentration for $\mathrm{Al}$ bound to biogenic opal $\left(\mathrm{Al}_{\mathrm{PART}}^{\mathrm{EQ}}\right)$ is derived from partition studies of $\mathrm{Al}$ between the particulate and dissolved phase [Moran and Moore, 1989]. The corresponding partition coefficient $\mathrm{k}_{\mathrm{d}}$ is essentially constant over the range of particle concentrations found in open ocean environments $(0.01$ to $1 \mathrm{mg} / \mathrm{l})$. It is important to stress at this stage, that we do not intend to provide a mechanistic description of $\mathrm{Al}$ removal on biogenic opal, but rather an empirically correct parameterization. While the order of magnitude of the partition coefficient is bound by experimental results $\left(\mathrm{k}_{\mathrm{d}} \approx 10^{6}\right.$ 1/kg [Moran and Moore, 1989]), the first-order rate constant for Al scavenging $(\kappa)$ is a free parameter. Its order of magnitude is adjusted to ensure the best correspondence between model output and observations.

\section{Dissolved Al Data}

[17] For the sake of this study, we have collated available data on dissolved $\mathrm{Al}$ in oceanic water. Two analytical techniques have been used for the measurement of dissolved Al: gas chromatography [Measures and Edmond, 1989] and fluorimetry using Lumogallion as complexing reagent [Hydes and Liss, 1976], respectively an adaptation to flow injection proposed by Resing and Measures [1994]. Results of both methods are consistent [Measures et al., 1986] and data obtained by either method are combined in a single data set (see Table 2 for data sources).

[18] Sites with published dissolved Al measurements are plotted in Figure 2. At the scale of the world ocean, few dissolved Al measurements are available. The data coverage is best within the equatorial Atlantic, a key region due to the high dust input from North African and Arabian deserts. Observations are however limited to the surface ocean only. This area of intense dust delivery is to be compared with the Central Pacific and the Southern Ocean,

Table 2. Sources of Dissolved Al Measurements

\begin{tabular}{|c|c|c|}
\hline Cruise & Dates & Source \\
\hline \multicolumn{3}{|c|}{ Atlantic } \\
\hline EN107 & $11 / 83$ & Measures et al. [1984] \\
\hline METEOR & $3-4 / 82$ & Kremling [1985] \\
\hline SAVE & $2 / 88$ & Measures and Edmond [1990] \\
\hline IOC 90 & $3 / 90$ & Measures [1995] \\
\hline IOC96 & $6 / 96$ & Vink and Measures [2001] \\
\hline ANTVIII/7 & $5 / 90$ & $\begin{array}{c}\text { Helmers and Rutgers van der } \\
\text { Loeff [1993] }\end{array}$ \\
\hline ANTIX/1 & $10-11 / 90$ & $\begin{array}{c}\text { Helmers and Rutgers van der } \\
\text { Loeff [1993] }\end{array}$ \\
\hline \multicolumn{3}{|c|}{ Pacific } \\
\hline MC-80 & $9-10 / 80$ & Orians and Bruland [1986] \\
\hline Vertex & $6-7 / 84$ & Orians and Bruland [1986] \\
\hline New Zealand & & Measures and Vink [2000] \\
\hline South. Ocean Proc. Study & $\begin{array}{l}\text { Southern Ocean } \\
10 / 94-1 / 96\end{array}$ & $\begin{array}{c}\text { U.S.JGOFS database - C. } \\
\text { Measures }\end{array}$ \\
\hline Arabian Sea Proc. Study & $\begin{array}{l}\text { Arabian Sea } \\
10 / 97-3 / 98\end{array}$ & $\begin{array}{c}\text { U.S.JGOFS database - C. } \\
\text { Measures }\end{array}$ \\
\hline
\end{tabular}




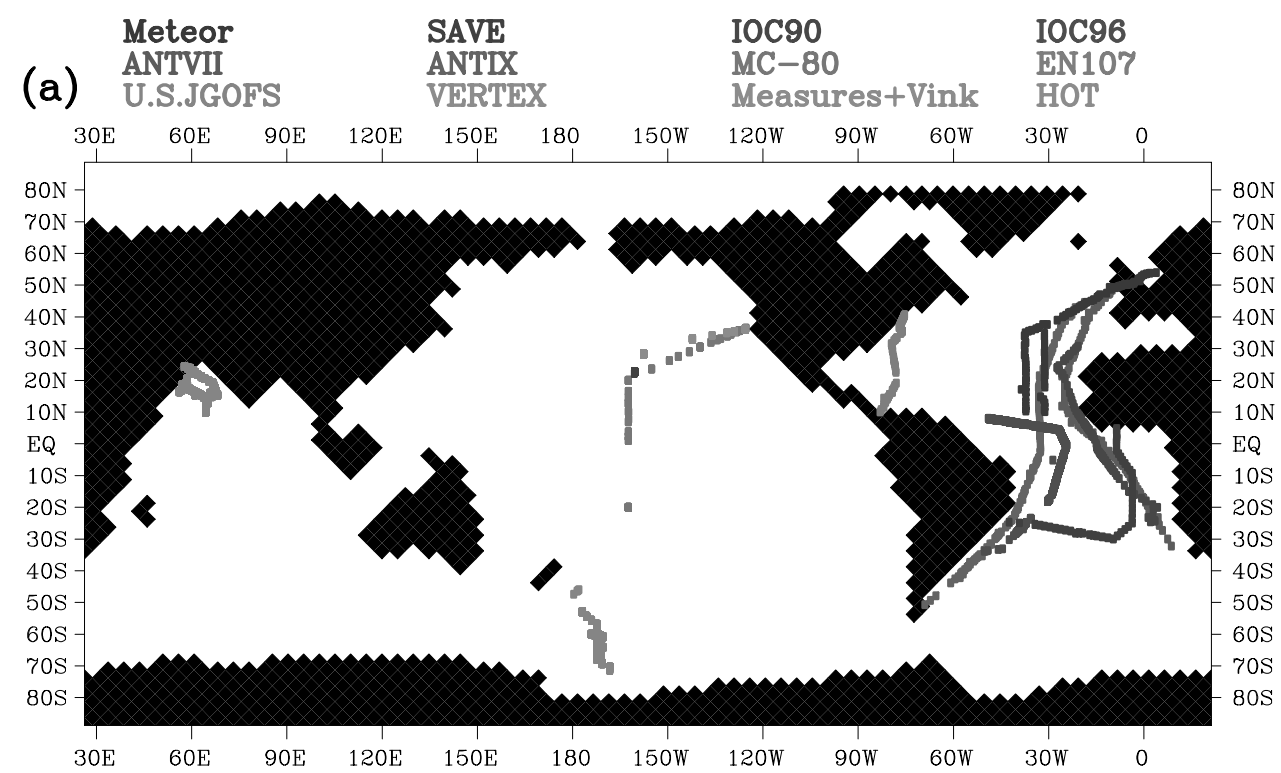

(b) dissolved Al [nmol/l]

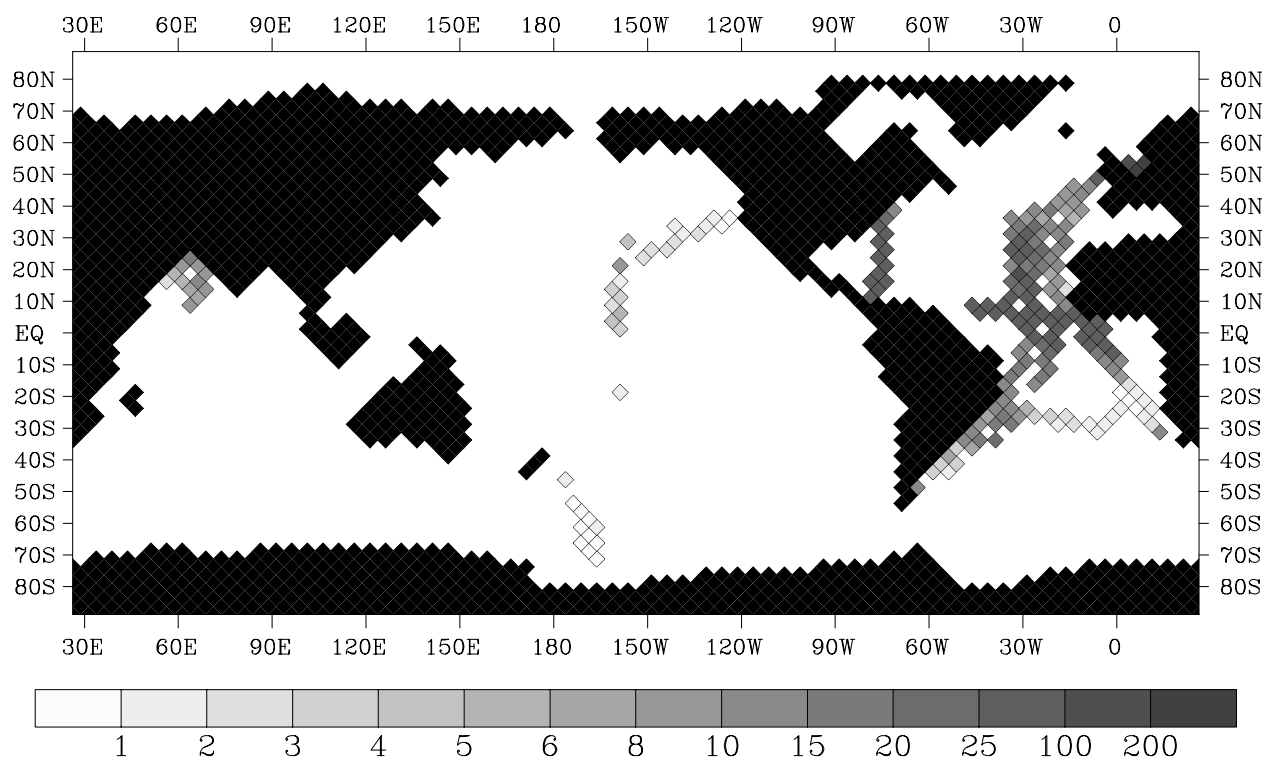

Figure 2. Location of dissolved Al measurements compiled from cruises listed in Table 2. (a) Individual cruise tracks and (b) corresponding measured surface ocean dissolved Al concentrations as averages over a model grid cell $\left(3.5^{\circ} \times 3.5^{\circ}\right)$. See color version of this figure at back of this issue.

for which surface and depth-dependent dissolved Al concentrations are available. The last data cluster concerns the Arabian Sea, a region of strong seasonal variability in dust input.

\section{Model Results}

\subsection{Standard Run}

[19] The Si cycle simulation is carried out as in the control run of Heinze et al. (submitted manuscript, 2002). The only difference is that biological production is also allowed to a small extent below sea ice through scaling of the nutrient uptake kinetics by the factor $0.1 /$ (sea ice thickness (m)).
This modification provides non zero opal concentrations in the water column below sea ice cover and hence corresponding scavenging of dissolved Al. Omitting this would lead to unrealistically high concentrations of dissolved $\mathrm{Al}$ in ice covered areas. The physical model does not provide sea ice compactness explicitly. The parameterization applied assumes, that the ice-free fraction increases with decreasing ice thickness. The simulated export production of biogenic opal is shown in Figure 3.

[20] The solubility of the aluminosilicate fraction is set to $3 \%$. In order to equilibrate particle surfaces with respect to dissolved $\mathrm{Al}$ throughout the water column, a scavenging rate constant of 10000 per year is applied. The order of 


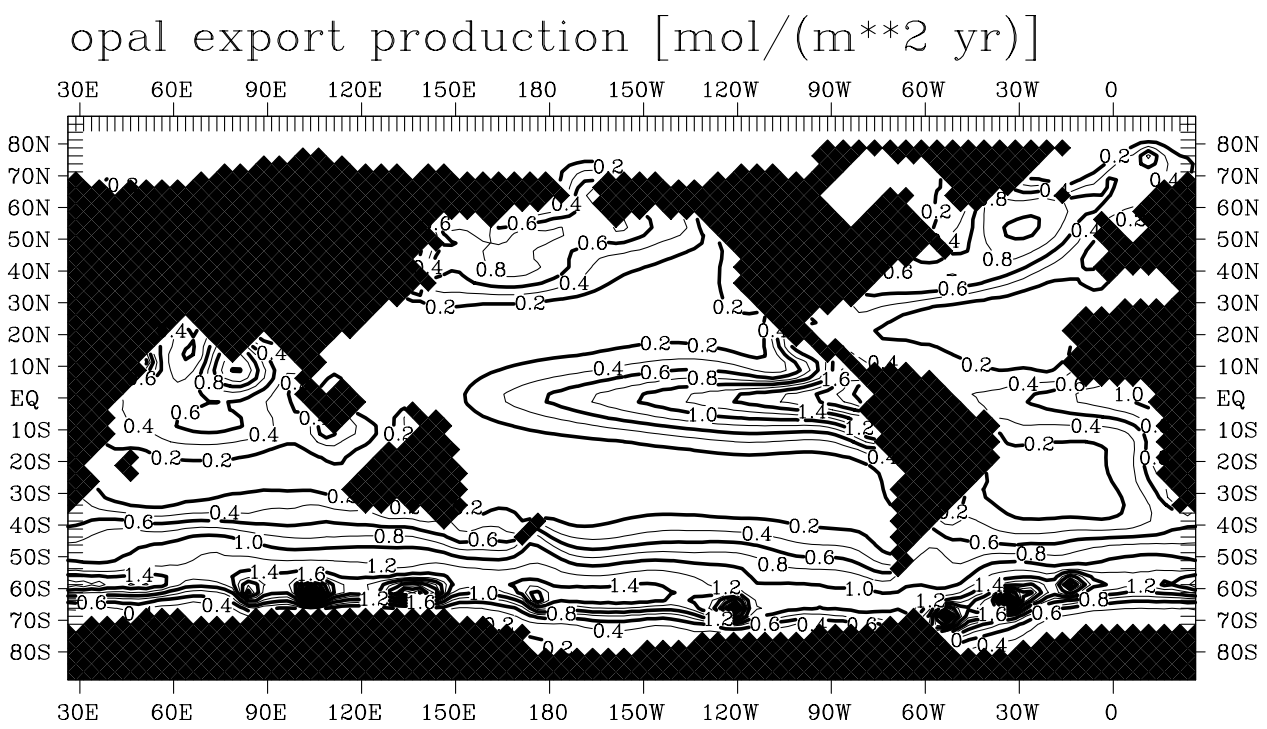

Figure 3. Annual export production of biogenic opal simulated by HAMOCC2s.

magnitude of scavenging kinetics is compatible with the rapid uptake of dissolved Al by siliceous particles [Moran and Moore, 1989, 1992]. Input of mineral aerosols to the surface ocean is provided by the dust field of Andersen et al. [1998] and shown in Figure 1a. The corresponding global annual dust delivery to the world ocean is compatible with the estimate by Duce et al. [1991].

[21] Modeled surface ocean dissolved Al levels are shown in Figure 4a, along with modeled meridional sections across the eastern and western Atlantic and the central Pacific, respectively plotted in Figures $4 \mathrm{~b}, 4 \mathrm{c}$ and $4 \mathrm{~d}$. The surface ocean dissolved $\mathrm{Al}$ distribution reflects the main source regions of mineral aerosols (North African and Arabian deserts, Central Asian and Australian deserts), which are identified by maximum levels of dissolved Al in the direction of dominant atmospheric transport. Below the mixed layer, the dissolved $\mathrm{Al}$ distribution is governed by advection of water masses and reaction on particle surfaces. North Atlantic Deep Water formation transports water enriched in dissolved $\mathrm{Al}$ to greater depths and results in a deep large scale maximum (Figure 4b, western Atlantic meridional section). While surface levels of dissolved $\mathrm{Al}$ modeled for Pacific Ocean waters (Figure 4c) correspond in their order of magnitude to published results, subsurface Pacific dissolved Al levels are overestimated by the model. The between basin fractionation with lower deep water levels in the Pacific compared to the Atlantic is reproduced.

[22] The model reproduces the main features of the dissolved Al distribution and corresponding surface water residence times can be computed. The residence time of dissolved $\mathrm{Al}$ is evaluated by dividing its water column inventory by the input rate from partial dissolution of mineral aerosols. The Al inventory reflects the non-linear interplay of dust delivery, scavenging to biogenic opal and advection. The resulting distribution is presented in Figure 5. Calculated residence times vary widely across oceanic regions, emphasizing the bias associated with dust input estimates derived from an inverse approach [Measures and Brown, 1996; Measures and Vink, 2000] using a constant residence time. Computed residence times scale with opal production. Low levels of opal production together with low rates of dust deposition result in high residence times. Areas under ice cover provide an extreme example of this combination. On the contrary, high rates of dust delivery combined to high opal production result in short residence times.

\subsection{Solubility of Aluminosilicate Fraction}

[23] The model sensitivity with respect to the solubility of the aluminosilicate dust fraction is addressed by model simulations identical to the control run, but solubilities of $1.5 \%, 6.0 \%$ and $12 \%$. In Figure 6 , the difference between modeled dissolved Al levels and the observations is plotted as a function of the latitude for Atlantic Ocean data for all 4 values of the solubility. While the spatial pattern of the resulting dissolved $\mathrm{Al}$ distribution is not affected by the different solubilities, the concentrations increase quasi-linearly with solubility. Assuming a release of Al to surface ocean waters corresponding to both, 6.0 and $12 \%$ of the $\mathrm{Al}$ content of mineral aerosols results in mostly overestimated dissolved Al levels. The correspondence between model results and data is improved for solubilities of 1.5 and $3.0 \%$. The differences between simulated and measured values reveal however a latitudinal seesaw pattern with too high modeled values north and too low values south of the equator.

\subsection{Varying Dust Input Fields}

[24] In order to check the capability of the ocean biogeochemical model to discriminate between different mineral aerosol input fields, the standard simulation was repeated by forcing the dissolved Al distribution with dust input derived from Mahowald et al. [1999]. The corresponding dust field is given in Figure 1b. This dust deposition field differs significantly from that of Andersen et al. [1998] with respect to peak input regions and magnitude of deposition. While the field by Mahowald et 
a dissolved Al [nmoles/1]

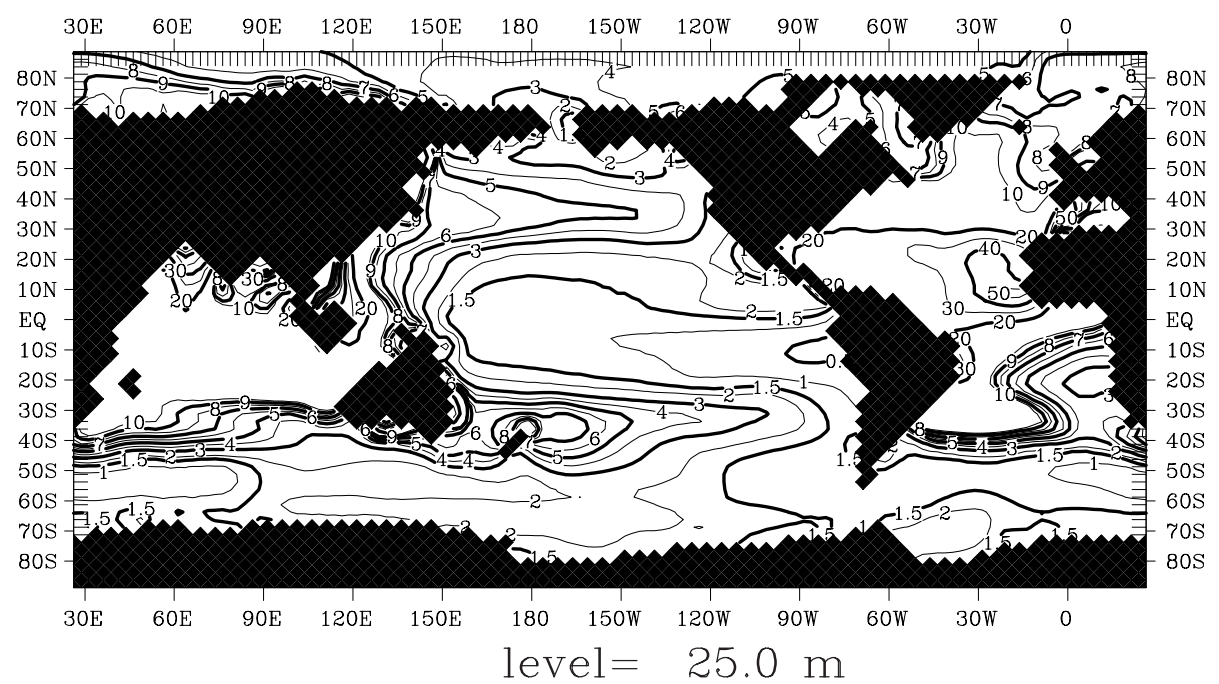

b dissolved Al [nmoles/1]

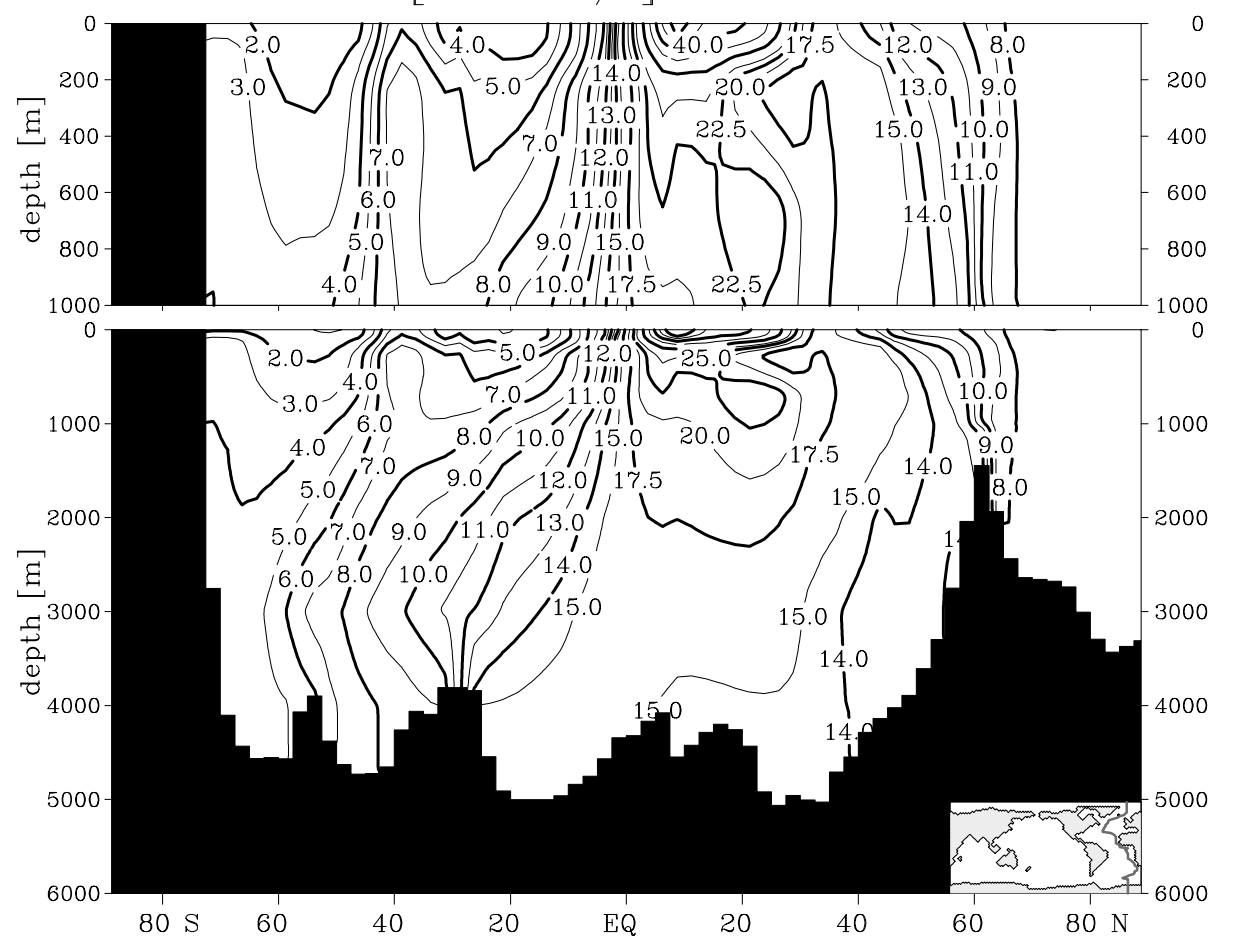

Figure 4. Modeled dissolved $\mathrm{Al}$ concentrations (nM) yielded by the standard run. Dust input after Andersen et al. [1998]. Solubility of aluminosilicate fraction $=3 \%$. (a) Surface ocean distribution and (b) meridional sections across the eastern Atlantic, (c) the western Atlantic and (d) the central Pacific.

al. [1999] predicts a significantly higher dust flux offshore Africa to tropical Atlantic surface waters, than suggested by Andersen et al. [1998], the latter suggests a larger source of mineral aerosols to the Pacific Ocean derived from Chinese and Australian deserts.

[25] The resulting surface ocean dissolved Al distribution (Figure 7a) reflects the spatial distribution of sources derived from the dust field. The general pattern emerging from the meridional sections across the Atlantic and Pacific
Ocean (Figures 7b, 7c and 7d) does not change significantly for a switch of dust fields. Dust input according to Mahowald et al. [1999], however, leads to higher levels of dissolved Al throughout the Atlantic Ocean as compared to a forcing with the field proposed by Andersen et al. [1998]. The latter results on the other hand in higher dissolved $\mathrm{Al}$ concentrations in the Pacific basin.

[26] The difference between both dust fields is emphasized for individual Atlantic cruise tracks in Figure 8 
c dissolved Al [nmoles/l]

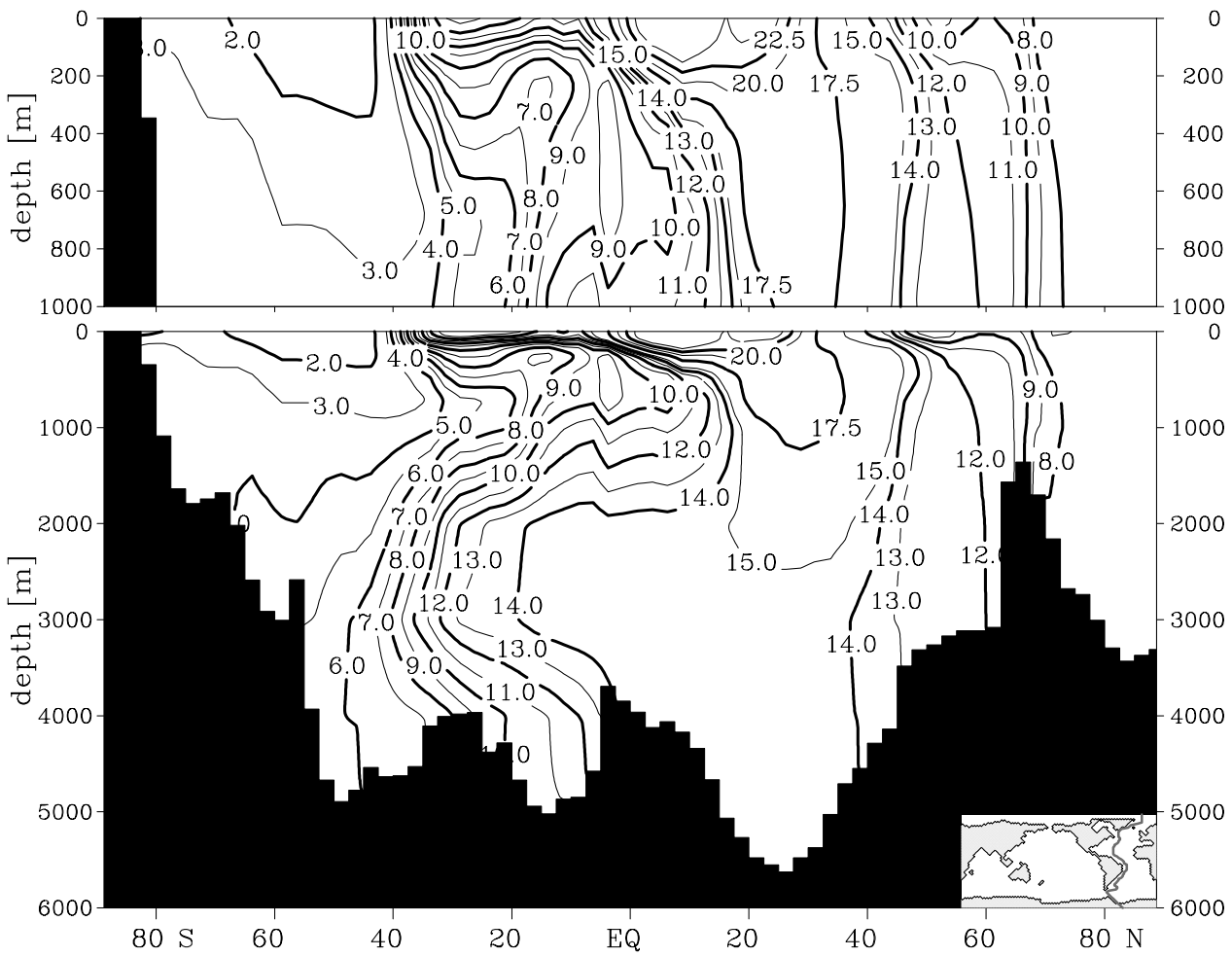

d dissolved Al [nmoles/l]

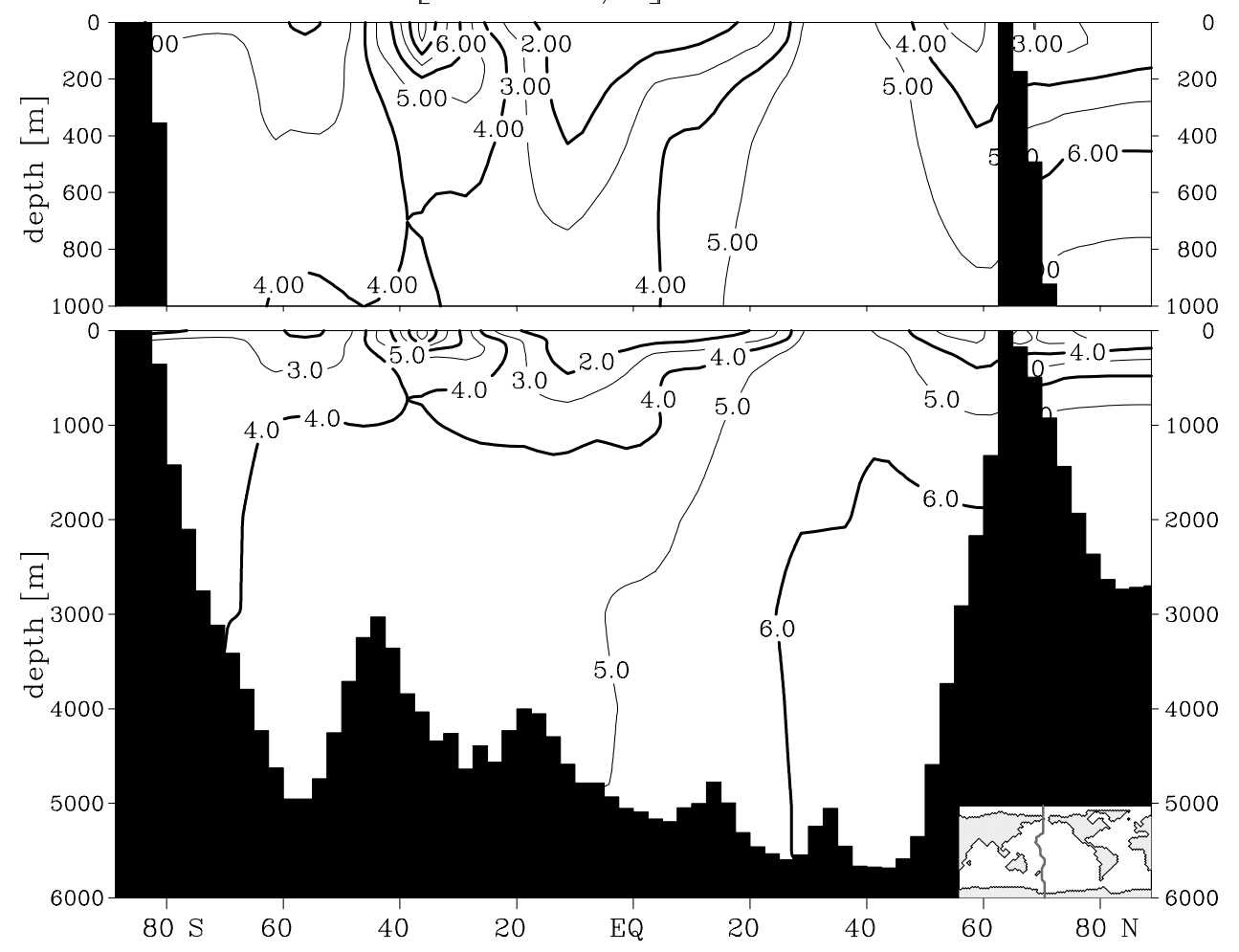

Figure 4. (continued) 


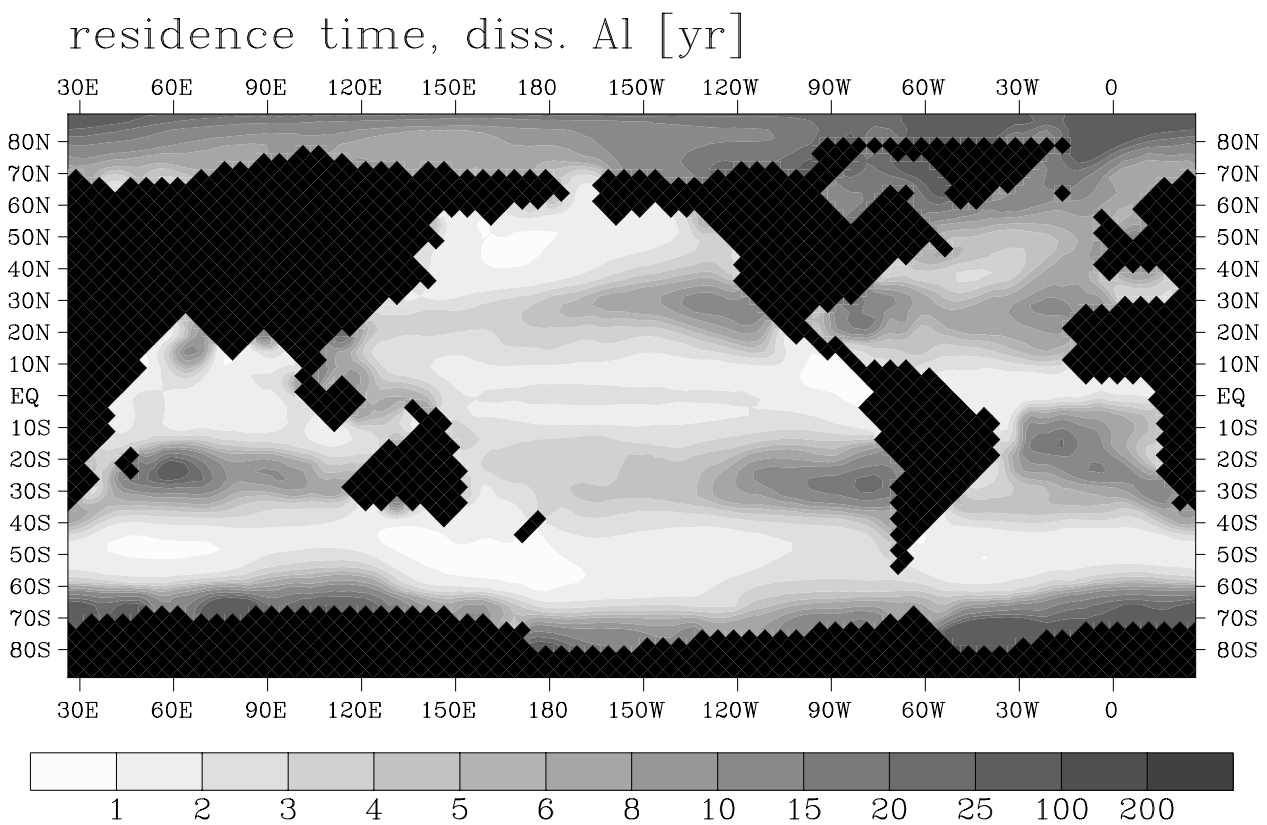

Figure 5. Residence times for dissolved $\mathrm{Al}$ in surface waters computed for the standard run. Dust input after Andersen et al. [1998]. Solubility of aluminosilicate fraction $=3 \%$. See color version of this figure at back of this issue.
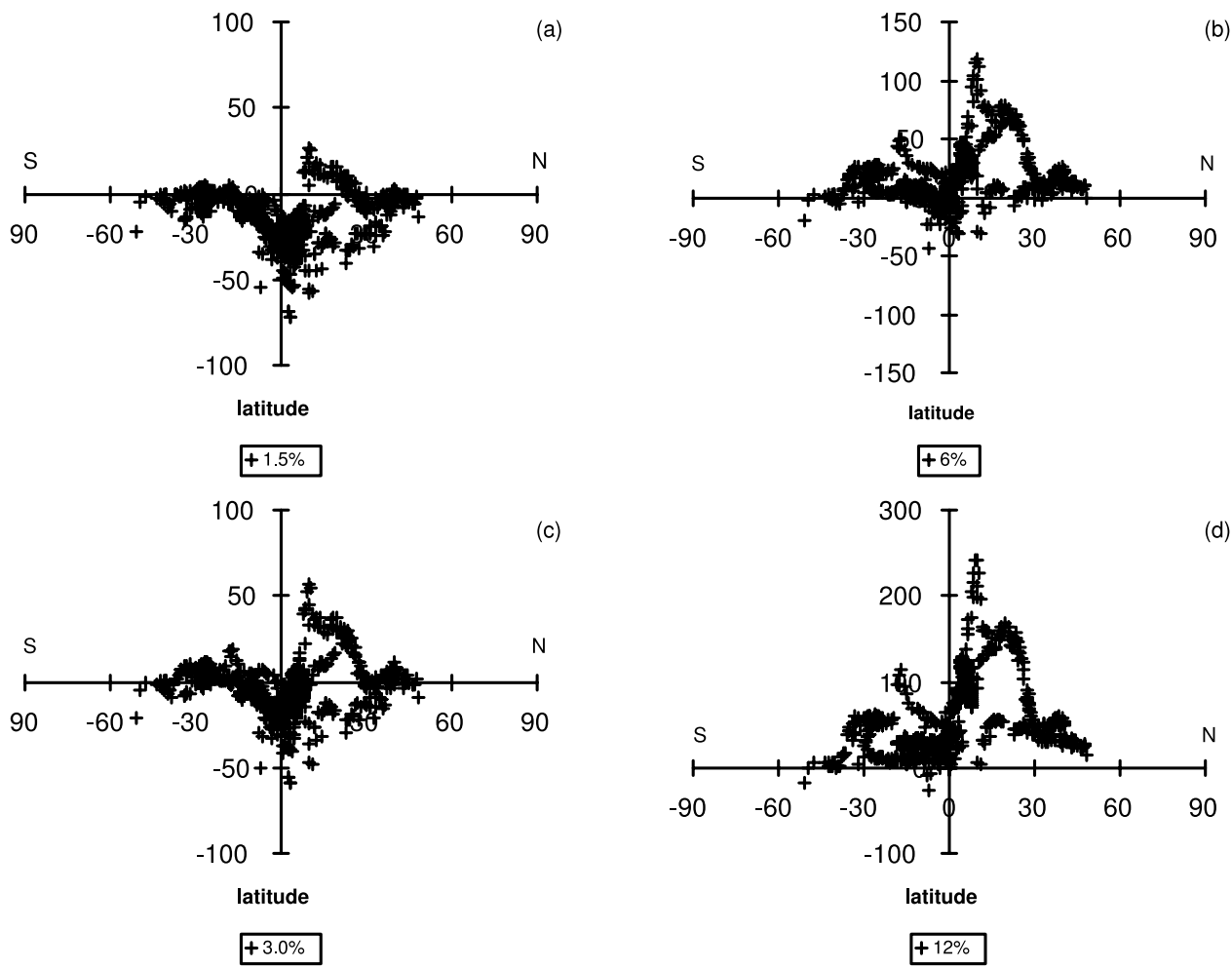

Figure 6. Comparison between modeled and observed dissolved Al concentrations for the Atlantic ocean for varying solubilities of the alumino silicate fraction. The difference between model output and data (nM) is plotted as a function of latitude. Dust input after Andersen et al. [1998]. (a) Solubility of $1.5 \%$; (b) solubility of $6.0 \%$; (c) solubility of $3.0 \%$; (d) solubility of $12 \%$. 
a dissolved Al [nmoles/l]

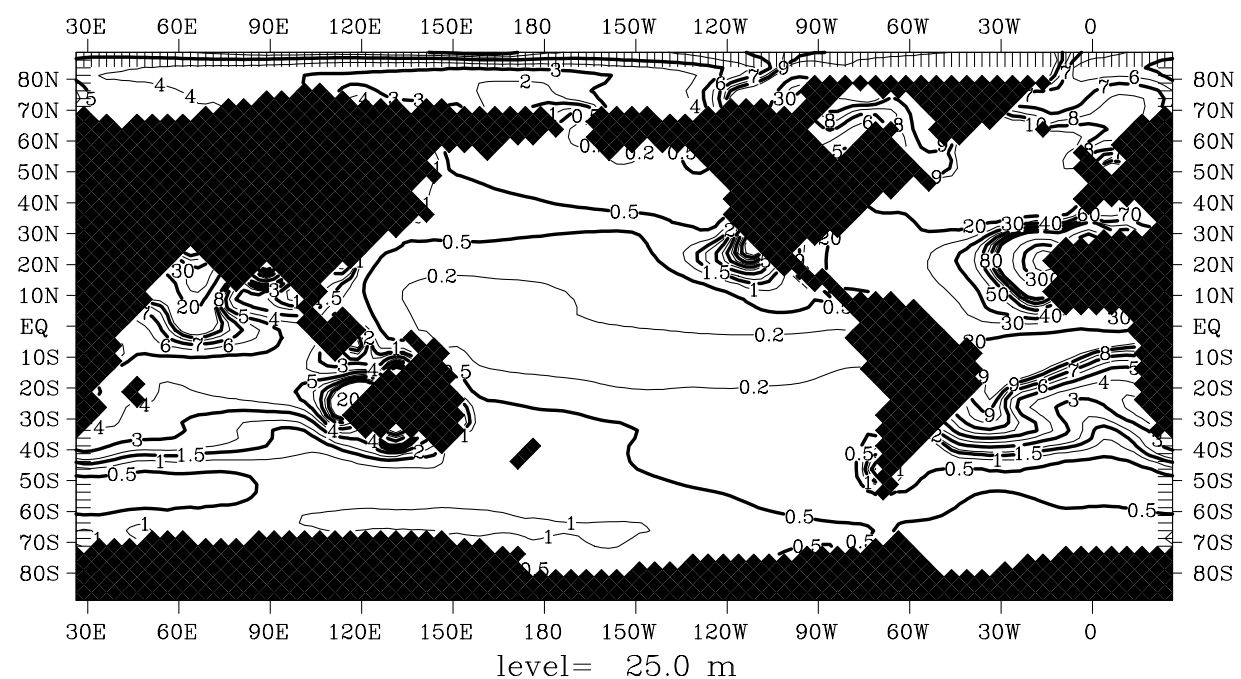

b dissolved Al [nmoles/l]

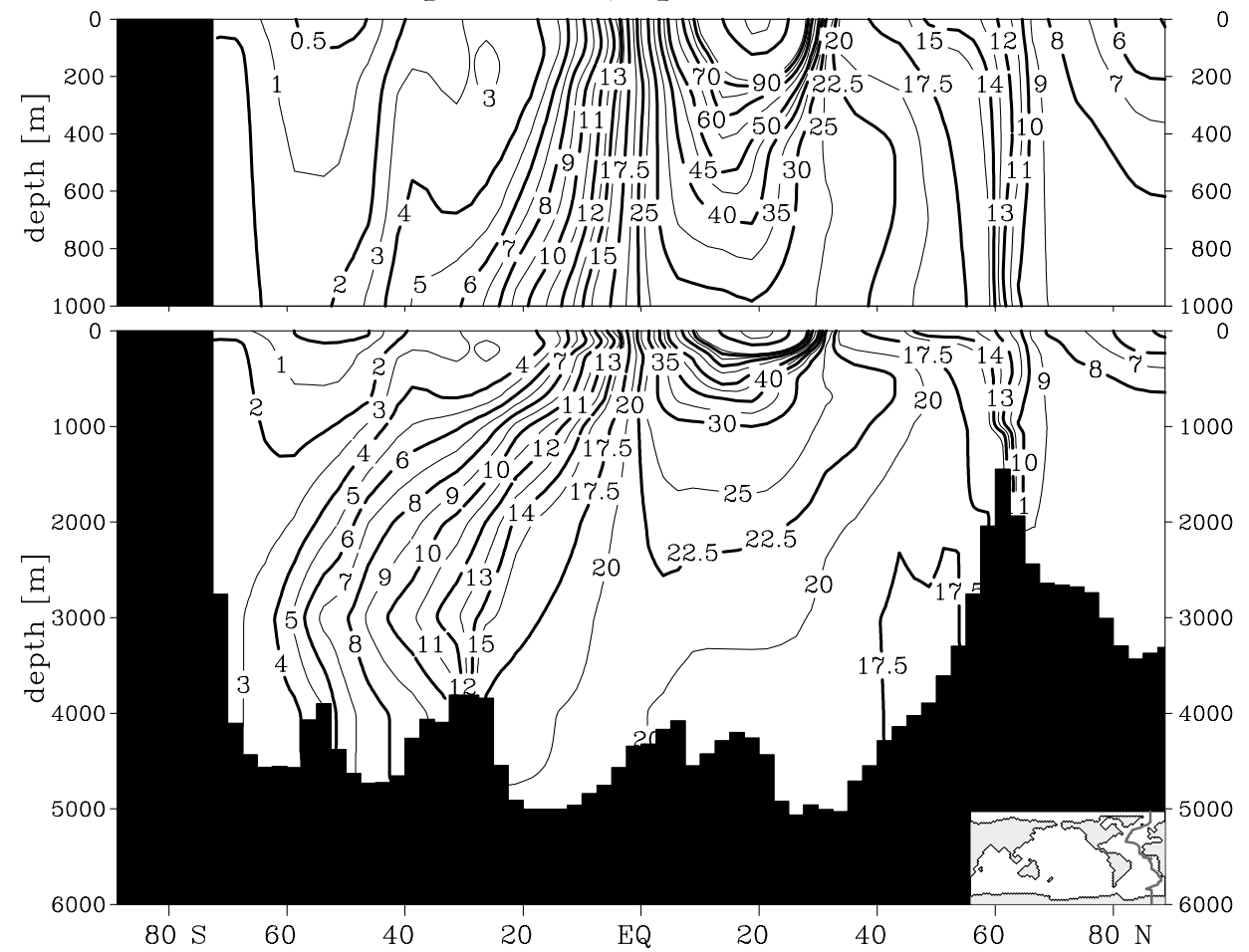

Figure 7. Modeled dissolved $\mathrm{Al}$ concentrations $(\mathrm{nM})$ yielded by the standard run. Dust input after Mahowald et al. [1990]. Solubility of aluminosilicate fraction $=3 \%$. (a) Surface ocean distribution and (b) meridional sections across the eastern Atlantic, (c) the western Atlantic and (d) the central Pacific.

[Andersen et al., 1998] and Figure 9 [Mahowald et al., 1999]. Comparing model results and measurements along an eastern section reveals a satisfying agreement between predicted and observed dissolved Al levels for the Andersen et al. [1998] field (Figure 8a). The maximum of dissolved $\mathrm{Al}$ is in the right order of magnitude. Model results yield a band of increased dissolved $\mathrm{Al}$ levels extending from $30^{\circ} \mathrm{N}$ to $10^{\circ} \mathrm{S}$, opposed to the measured distribution with displays a narrow maximum between $15^{\circ} \mathrm{N}$ and $10^{\circ} \mathrm{S}$. Figure $8 \mathrm{~b}$ represents a data-model comparison for a transect across the western Atlantic. Model results reflect the attenuation of dust input with increasing distance from the source. The east-west trend in dissolved $\mathrm{Al}$ concentrations is further evidenced for a transect north (Figure 8c), respectively south of the equator (Figure $8 \mathrm{~d}$ ). While the model-data comparison yields a satisfying agreement north of the equator, modeled dissolved $\mathrm{Al}$ levels are slightly overestimated on the southern section. 


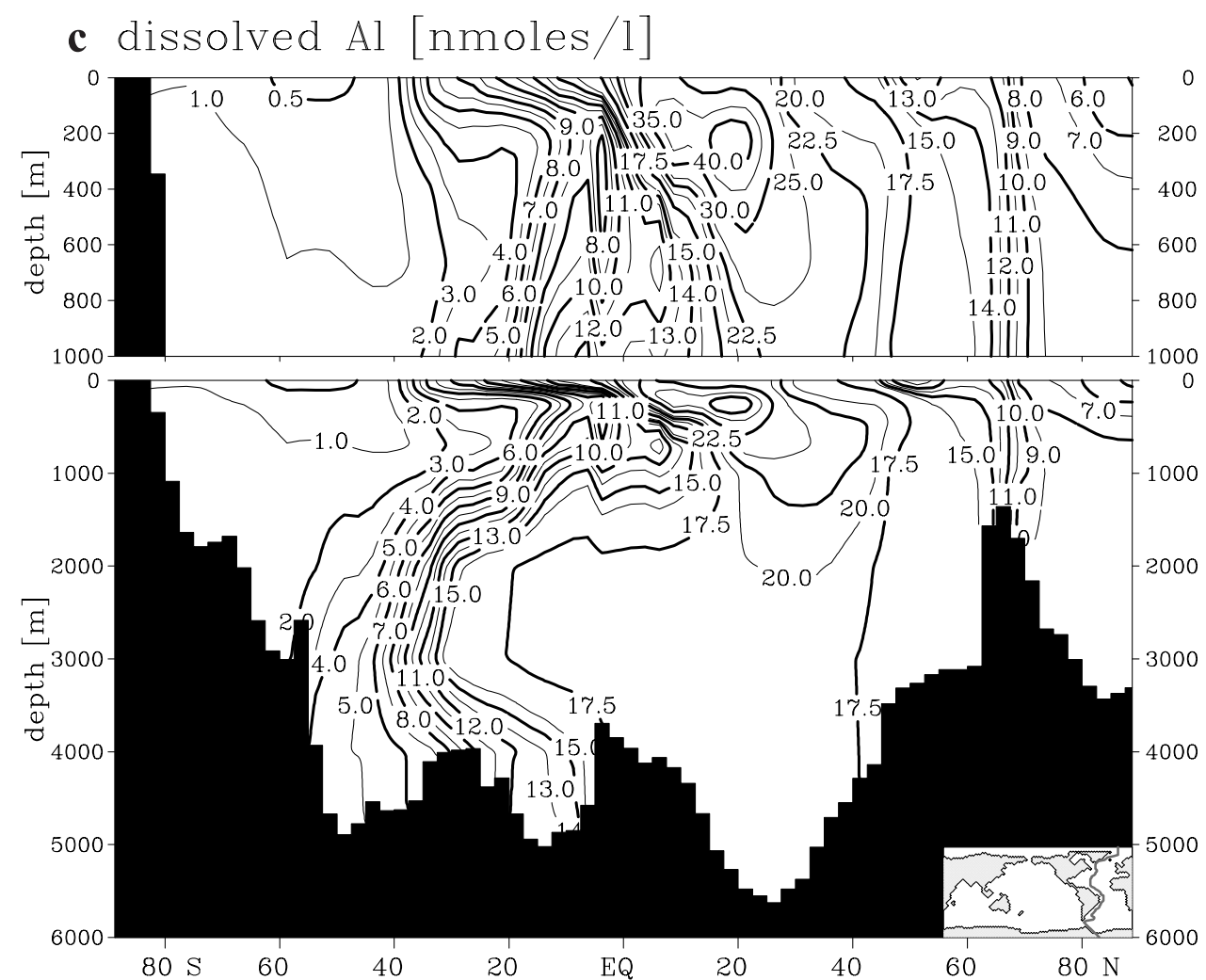

d dissolved Al [nmoles/l]

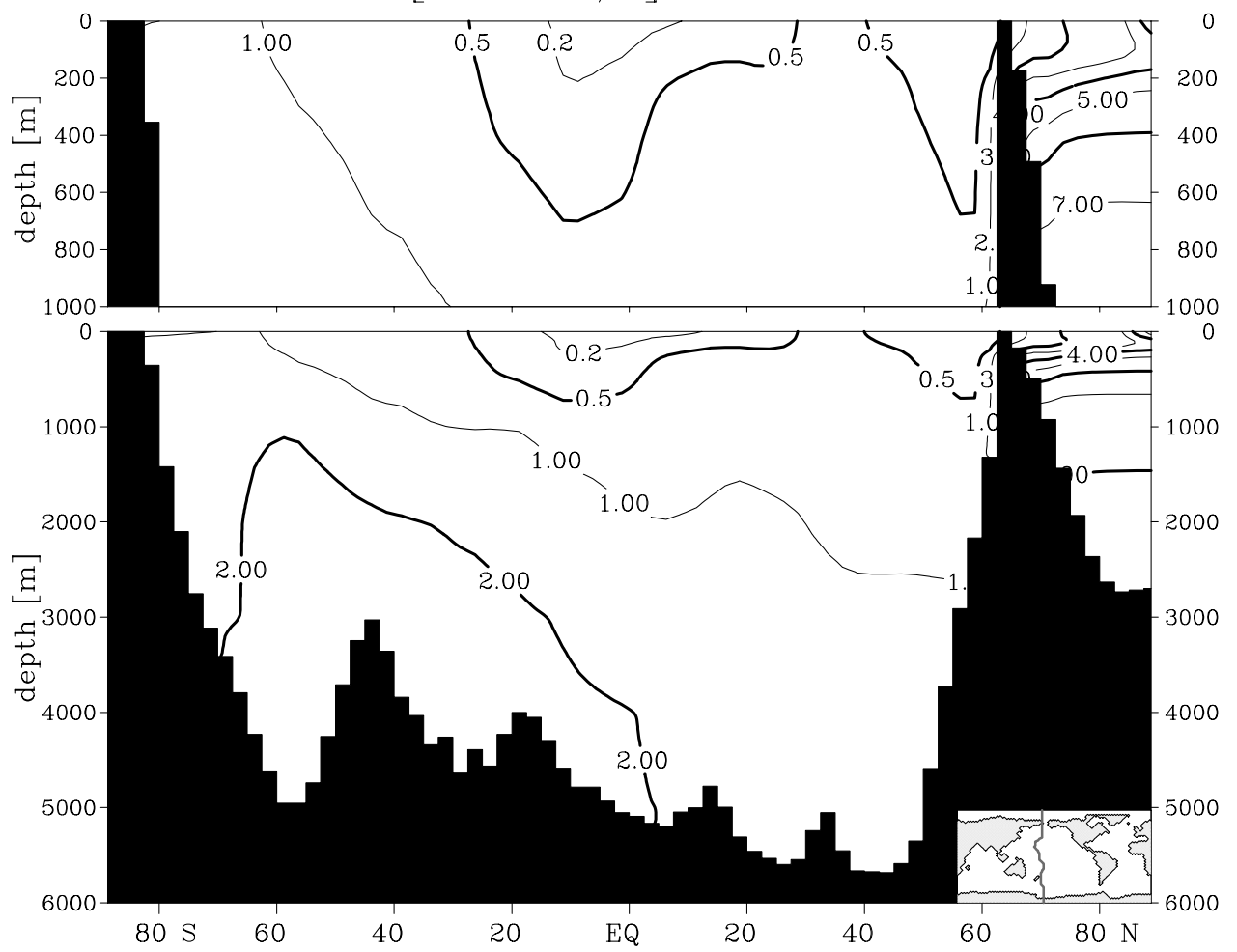

Figure 7. (continued) 

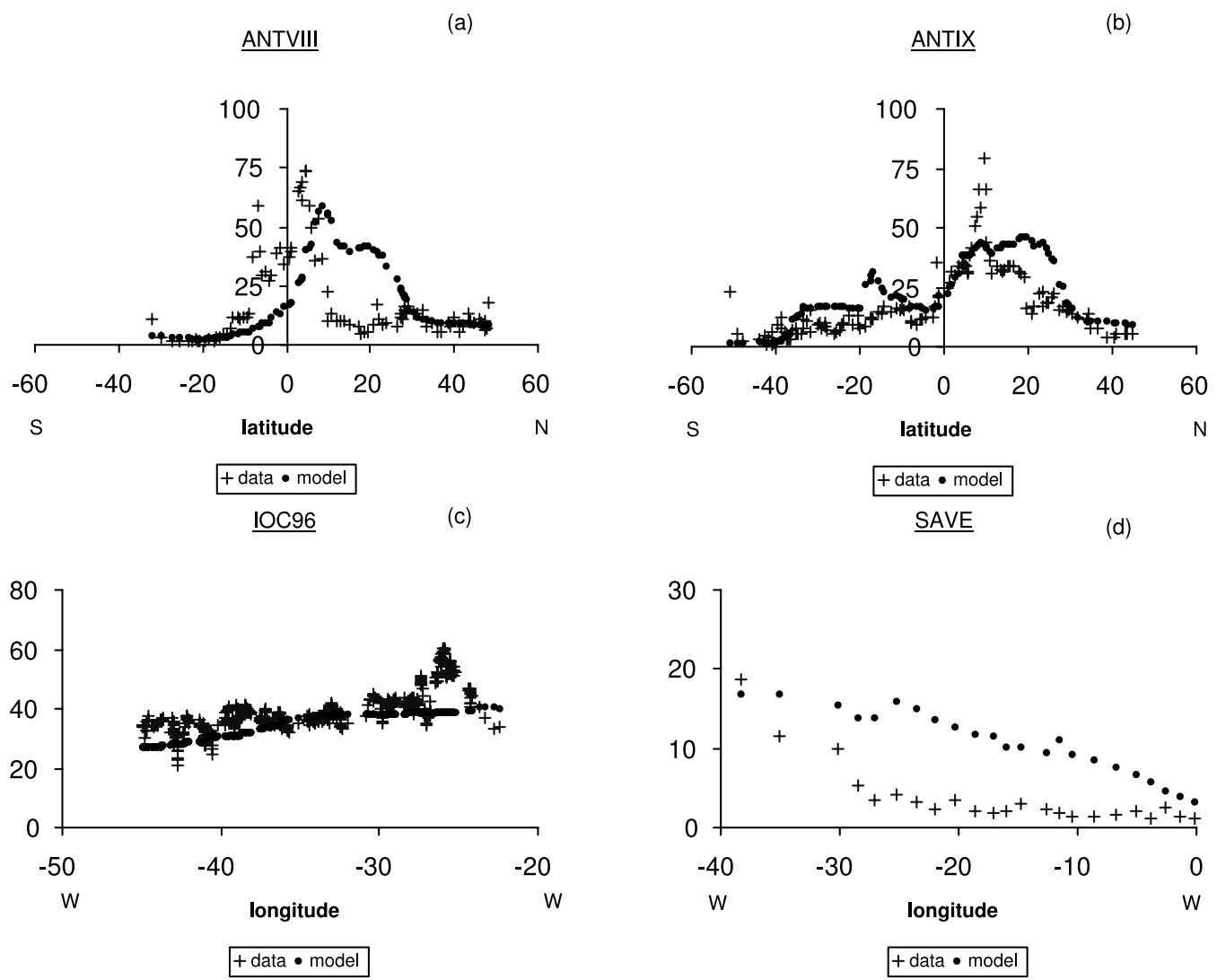

Figure 8. Data model comparison for surface ocean dissolved Al concentrations (nM) along individual Atlantic ocean cruise tracks. Dust input after Andersen et al. [1998]. Solubility of aluminosilicate fraction $=3 \%$. (a) cruise ANT VIII [Helmers et al., 1993] following the African coast line; (b) cruise ANT IX [Helmers and Rutgers van der Loeff, 1993] following the South American coastline up to the equator and proceeding northward along $25^{\circ} \mathrm{W}$; (c) subsample of IOC 96 data set along a longitudinal transect extending from $4^{\circ} \mathrm{N} 22^{\circ} \mathrm{W}$ to $8^{\circ} \mathrm{N} 45^{\circ} \mathrm{W}$; (d) subsample of SAVE data set [Measures and Edmond, 1990] along a longitudinal transect extending from $25^{\circ} \mathrm{S} 38^{\circ} \mathrm{W}$ to $26^{\circ} \mathrm{S} 0^{\circ} \mathrm{W}$.

[27] The same data-model comparison is carried out for dissolved Al distributions as obtained by applying a dust input according to Mahowald et al. [1999]. The model predicts unrealistically high dissolved Al levels between $10^{\circ}$ and $35^{\circ} \mathrm{N}$ (Figures $9 \mathrm{a}$ and $9 \mathrm{~b}$ ). The model qualitatively reproduces the northern east-west trend (Figure 9c), but calculated dissolved Al concentrations show a constant offset toward higher levels. South of the equator, observations along a longitudinal transect are well reproduced (Figure 9d), reflecting the lower south Atlantic deposition prediction of Mahowald et al. [1999].

[28] The comparison between dissolved Al distributions predicted by the two different dust fields is extended to the Sargasso Sea (Figure 10a), the Pacific (Figure 10b), the Southern Ocean (Figure 10c) and the Arabian Sea (Figure 10d). The western Atlantic transect shown in Figure 10a intercepts shelf regions and crosses the Sargasso Sea. While the model does not resolve coastal and shelf areas, model output and data for the Sargasso Sea (enclosed symbols) can be compared with each other. The model consistently predicts too low levels of dissolved Al, suggesting an underestimation of dust delivery to this remote region. Modeled dissolved Al levels are overestimated for both dust fields in Southern Ocean surface waters (Figure 10c). In line with a higher dust flux to the Antarctica predicted by Andersen et al. [1998], calculated dissolved Al levels are consistently higher in this area. Both dust fields yield similar, although overestimated dissolved $\mathrm{Al}$ concentrations in the Arabian Sea (Figure 10d).

[29] Simulated profiles of dissolved Al are compared to measured ones for Pacific Ocean sampling sites in Figure 11. They further stress the differences between dust fields. In line with decreased dust delivery to the Central Pacific Ocean predicted by Mahowald et al. [1999], dissolved Al profiles are five times lower than those obtained from the Andersen et al. [1998] field. While the order of magnitude of dissolved $\mathrm{Al}$ corresponds well to the measured profiles for the simulation forced with the former, the measured surface maximum is not present on modeled profiles.

\section{Discussion}

\subsection{Validity of Model Approach: Standard Run}

[30] The overall poor coverage of dissolved Al measurements makes it impossible to interpolate observations in 
(a)
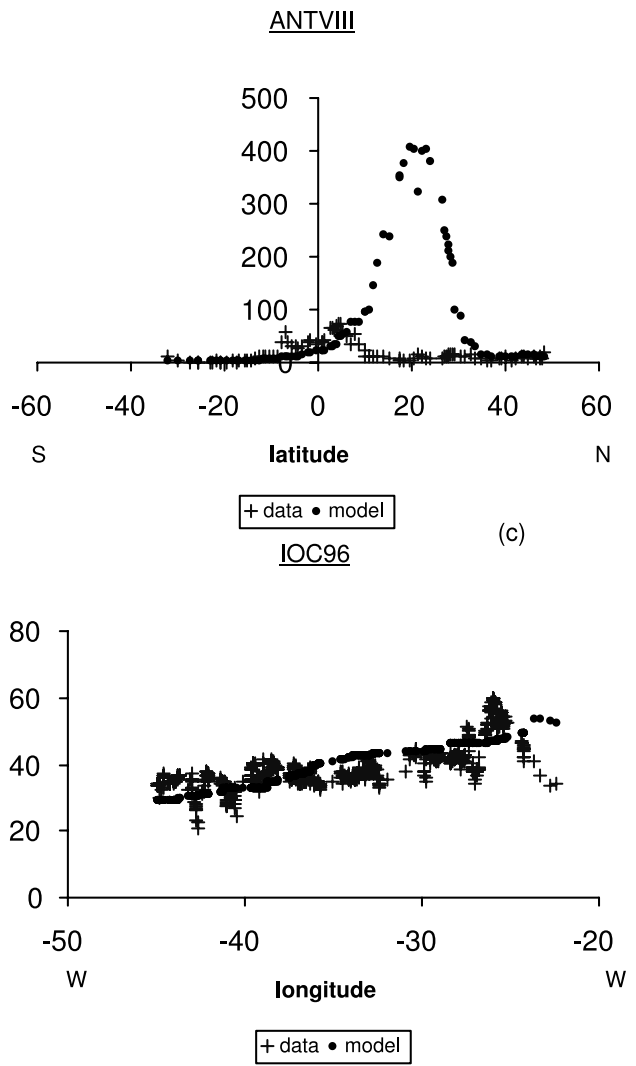

(b)
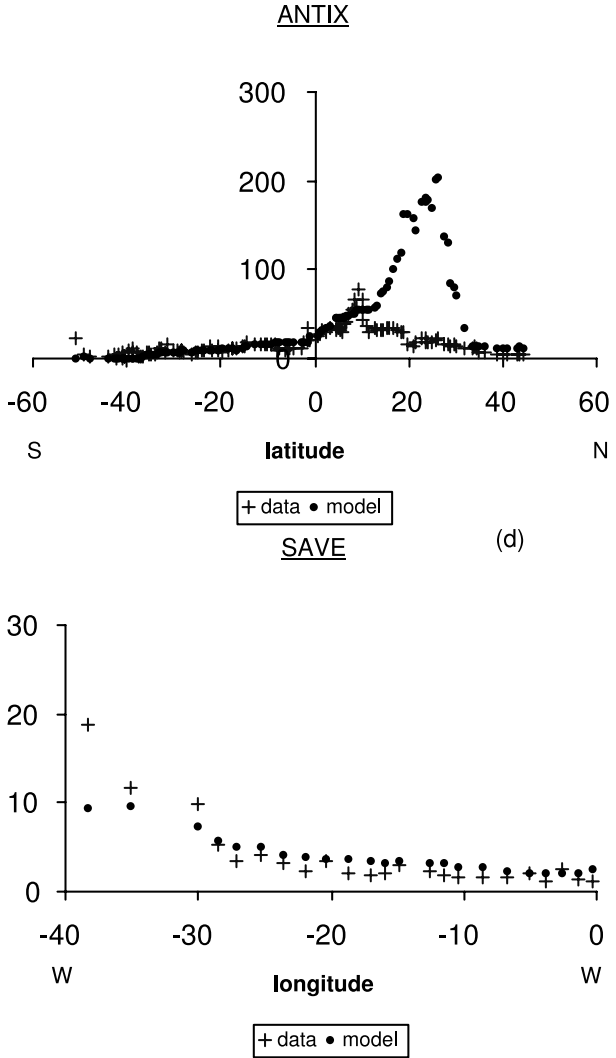

Figure 9. Data model comparison for surface ocean dissolved Al concentrations (nM) along individual Atlantic ocean cruise tracks. Dust input after Mahowald et al. [1990]. Solubility of aluminosilicate fraction $=3 \%$. (a) cruise ANT VIII [Helmers and Rutgers van der Loeff, 1993] following the African coast line; (b) cruise ANT IX [Helmers and Rutgers van der Loeff, 1993] following the South American coastline up to the equator and proceeding northward along $25^{\circ} \mathrm{W}$; (c) subsample of IOC 96 data set along a longitudinal transect extending from $4^{\circ} \mathrm{N} 22^{\circ} \mathrm{W}$ to $8^{\circ} \mathrm{N} 45^{\circ} \mathrm{W}$; (d) subsample of SAVE data set along a longitudinal transect extending from $25^{\circ} \mathrm{S} 38^{\circ} \mathrm{W}$ to $26^{\circ} \mathrm{S} 0^{\circ} \mathrm{W}$.

order to reconstruct a global distribution for the surface ocean. Hence a direct comparison between modeled and observed Al distributions on the scale of the world ocean is not accessible. Next to the spatial coverage of data, their temporal resolution is critical. Dust input to the surface ocean is highly episodic in nature. Discreet observations might be biased toward high or low flux periods. While this bias will be less important in areas with extensive data coverage (tropical Atlantic), it might contribute to the discrepancy between model results and data discussed in the following sections. Despite the need for more measurements of dissolved Al, there are sufficient data in contrasting regions enabling a validation of the Al cycle implemented in the biogeochemical model. The regions are (1) the tropical Atlantic: high dust input and an opal export production between $10^{\circ} \mathrm{N}$ and $10^{\circ} \mathrm{S}$ ranging from 1.2 to $0.5 \mathrm{~mol} / \mathrm{m}^{2} / \mathrm{yr}^{1}$ along a E-W transect; (2) the Central Pacific: low dust input and low opal export production outside the equatorial belt; (3) the Southern Ocean: low dust input and high opal export production (maximum values exceeding $1.8 \mathrm{~mol} / \mathrm{m}^{2} / \mathrm{yr}^{1}$ ); and (4) the Arabian Sea: high dust flux and opal export of $0.6 \mathrm{~mol} / \mathrm{m}^{2} / \mathrm{yr}^{1}$. All opal export fluxes are yearly averaged values (Figure 3).

[31] The distribution of dissolved Al in surface waters reflects the combined effect of input and rapid removal by scavenging to biogenic siliceous particles. This behavior is well reflected by model results. Maximum dissolved $\mathrm{Al}$ levels are associated with areas of enhanced dust delivery. Scavenging occurs throughout the water column leading to a subsurface minimum. As particle densities decrease with depth due to dissolution of biogenic opal, the equilibrium concentration between $\mathrm{Al}$ in the dissolved phase and $\mathrm{Al}$ bound to particle surfaces shifts toward lower values and $\mathrm{Al}$ is released from the carrier phase. This process does however not lead to a progressive enrichment of deep waters along the flow path from the North Atlantic to the North Pacific. While mineralization of particulate organic $\mathrm{C}$ results in increasing levels of nutrients with age of water masses, the ongoing scavenging of dissolved $\mathrm{Al}$ on particles settling to the deep waters along their flow path, results in decreasing dissolved $\mathrm{Al}$ concentrations. This peculiarity of 
(a)

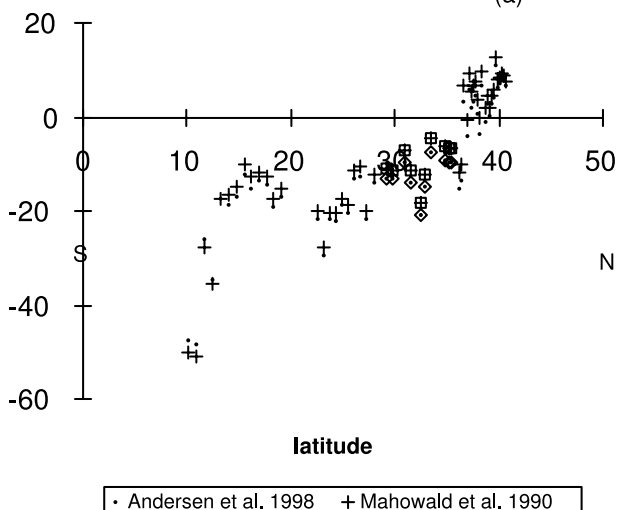

(c)

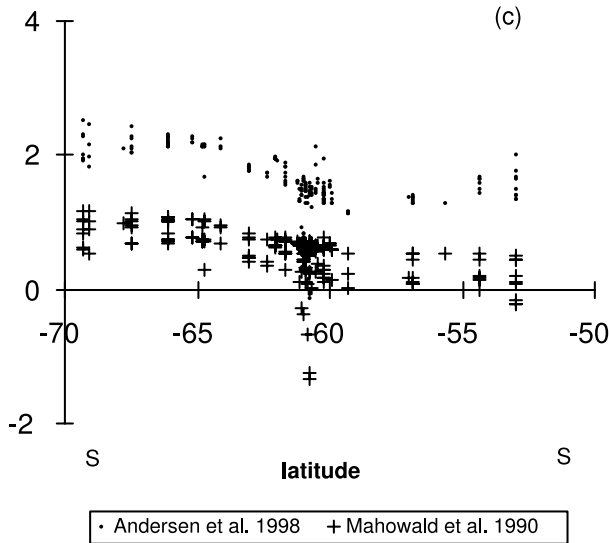

(b)

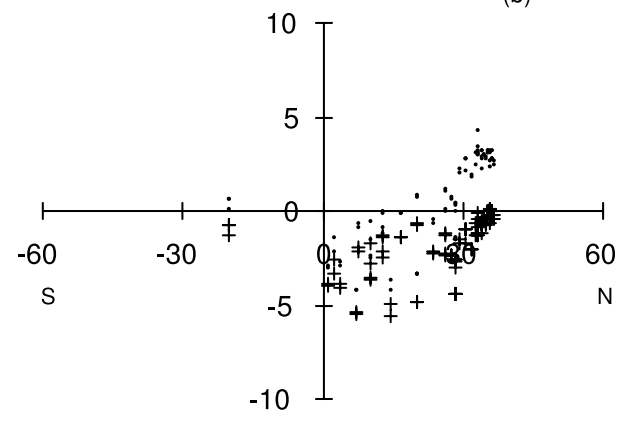

latitude

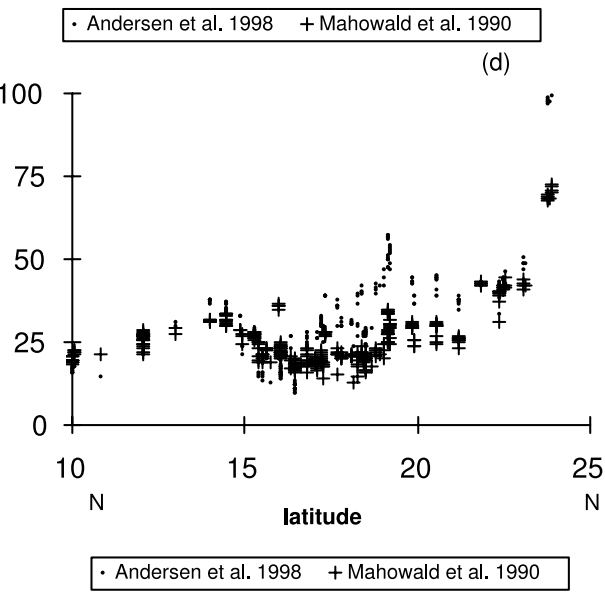

Figure 10. Comparison between modeled and observed dissolved $\mathrm{Al}$ concentrations for the different oceanic regions and different dust input fields. The difference between model output and data (nM) is plotted as a function of latitude. (a) Western Atlantic between $41^{\circ} \mathrm{N} 72^{\circ} \mathrm{W}$ and $10^{\circ} \mathrm{S} 80^{\circ} \mathrm{W}$. (b) Central Pacific Ocean between $33^{\circ} \mathrm{N} 221^{\circ} \mathrm{E}$ and $48^{\circ} \mathrm{S} 183^{\circ} \mathrm{E}$. (c) Southern Ocean between $53^{\circ} \mathrm{S} 185^{\circ} \mathrm{E}$ and $62^{\circ} \mathrm{S}$ $191^{\circ}$ E. (d) Arabian Sea.

between-ocean-basin-fractionation of deep water dissolved Al levels is well reproduced by the model.

\subsection{Solubility of Aluminosilicate Fraction}

[32] While the model qualitatively reproduces the global pattern of the dissolved $\mathrm{Al}$ distribution, large discrepancies emerge from a quantitative comparison of model output and observations on the regional scale. The observed departure between model results and observations might be explained in terms of process description (solubility of the aluminosilicate fraction) or reflect an unrealistic source of dust input to the surface ocean. As mentioned earlier, a solubility of the aluminosilicate fraction of continental aerosols ranging between 1.5 and $10 \%$ is reported [e.g., Maring and Duce, 1987; Prospero et al., 1987; Chester et al., 1993]. Due to the increase of $\mathrm{Al}$ solubility with decreasing solution $\mathrm{pH}$, the actual release of Al from continental dust might exceed $10 \%$. Solubilization of dust in rain [Prospero et al., 1987] and/or upon exposure of particles to low-pH environments following the ingestion by plankton organisms [Maring and Duce, 1987] are processes potentially increasing Al release to the surface ocean. We thus expect dust solubility to vary regionally and temporally as a result of acidification and time of exposure of aerosol particles to acidic conditions.
Assuming a dissolution of $6 \%$, respectively $12 \%$ of the $\mathrm{Al}$ bound to the aluminosilicate fraction of dust delivered to the surface ocean according to Andersen et al. [1998], results in an overestimation of dissolved $\mathrm{Al}$ levels of the world ocean. Model results suggest an Al solubility between 1.5 and 3\% and thus within the range of experimental results.

\subsection{Varying Dust Input Fields}

[33] Having discussed the ability of the model to reproduce the main characteristics of the world ocean dissolved Al distribution and demonstrated its sensitivity to the solubility of the aluminosilicate dust fraction, we will now address the capability of our approach to validate different dust input fields. As stated earlier, repeated simulations forced with the dust field of Andersen et al. [1998] suggest a solubility of the aluminosilicate fraction between $1.5 \%$ and $3 \%$. Assuming a solubility of $3 \%$ and changing the dust input function to Mahowald et al. [1999], results in unrealistic high levels of dissolved $\mathrm{Al}$ in surface waters of the tropical Atlantic (Figure 9). Because of the quasi-linear relationship between maximum levels of dissolved $\mathrm{Al}$ predicted by the model and the solubility of the aluminosilicate fraction, it can easily be seen that decreasing dust solubility would not improve the fit between model output 

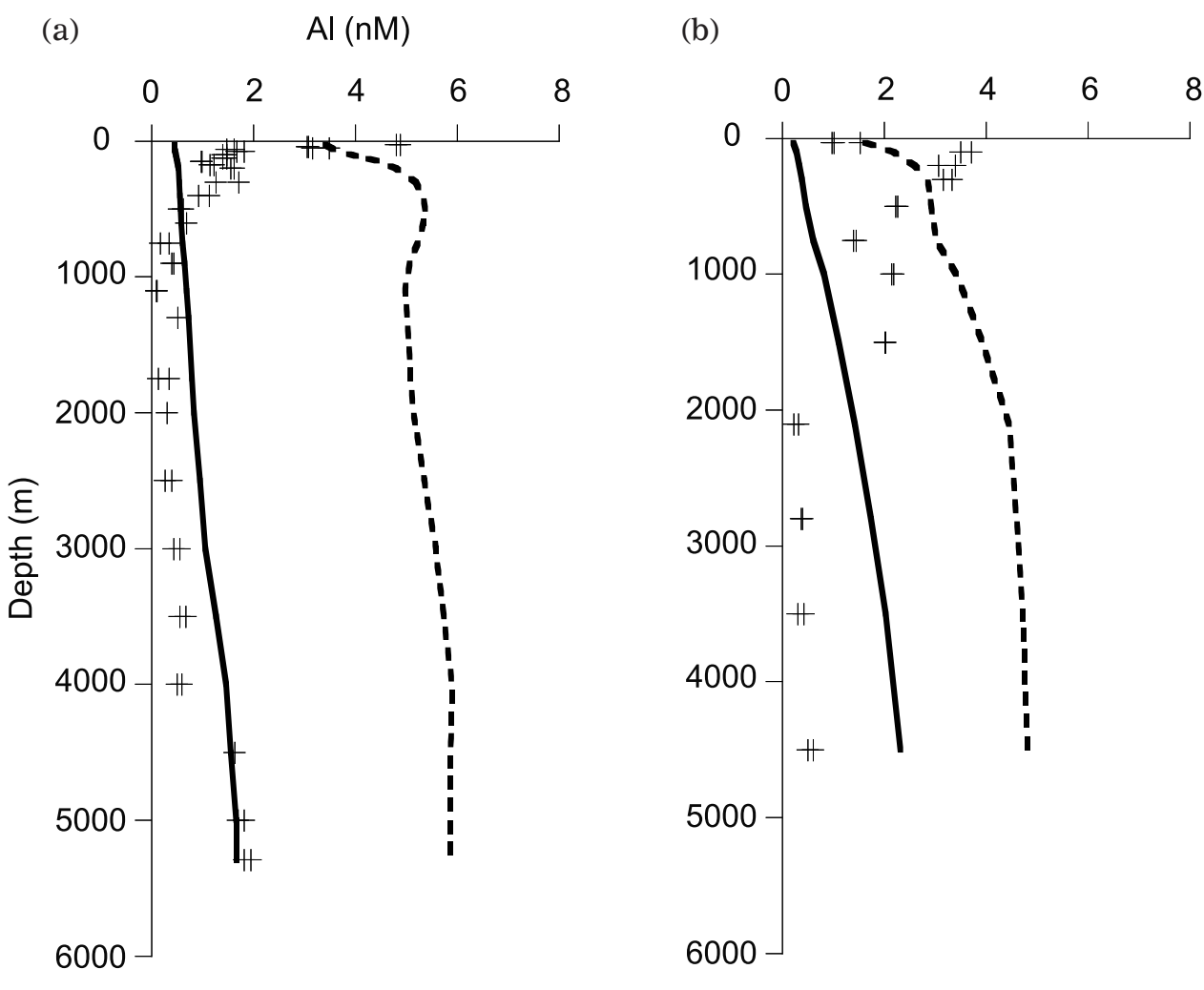

Figure 11. Data model comparison for dissolved $\mathrm{Al}$ profiles $(\mathrm{nM})$ versus depth of water column $(\mathrm{m})$ at two locations in the Pacific Ocean. (a) $28^{\circ} \mathrm{N} 204^{\circ} \mathrm{W}$. (b) $20^{\circ} \mathrm{S} 200^{\circ} \mathrm{W}$.

and observations. Our model results suggest a significant overestimation of dust delivery to the tropical Atlantic Ocean by Mahowald et al. [1999] and hence an overestimation of the corresponding source region. This overestimation is corroborated independently by a comparison with mineral aerosol fluxes given by Duce et al. [1991]. The comparison reveals that maximum values of dust deposition $\left(>27.4 \mathrm{~g} / \mathrm{m}^{-2} / \mathrm{d}\right.$ for Duce et al. [1991]; $>50.0 \mathrm{~g} / \mathrm{m}^{-2} / \mathrm{d}$ for Mahowald et al. [1999]), as well as the spatial extension of the region under maximal dust delivery are overestimated by Mahowald et al. [1999]. A slight overestimation of the northern African source was also inferred by Mahowald et al. [1999] from a comparison between calculated deposition fluxes and marine sediment core data. Modeled dissolved $\mathrm{Al}$ concentrations appear thus as a robust tracer of dust input to the tropical Atlantic.

[34] Opposed to the strong differences of maximum levels of dissolved $\mathrm{Al}$ distributions resulting from the two dust fields in tropical Atlantic surface waters, the data model comparison along the longitudinal transect north and south of the equator yields comparable results. The two dust fields (Figure 1a [Andersen et al., 1989] and Figure 1b [Mahowald et al., 1999]) differ in the latitudinal extension of maximum dust delivery and the sharpness of longitudinal gradients. North of the equator, along the cruise track selected for comparison (Figure $8 \mathrm{c}$ and Figure 9c), both fields deliver similar dust fluxes to the surface ocean. On the contrary, South of the equator, Andersen et al. [1989] predict a stronger east-west gradient, a pattern faithfully reproduced by the corresponding dissolved $\mathrm{Al}$ distribution. The surface ocean dissolved Al distribution thus primarily reflects mineral aerosol input.

[35] Both input fields predict similar dust fluxes to the surface ocean for the area of the Arabian Sea (Figure 10d) for which data are available. Simulated dissolved Al levels are comparable and overestimated when compared to the observations. The Arabian sea experiences episodic high levels of dust input derived from northeast Africa. A strong seasonal signal in export production linked to the monsoon system and resulting upwelling is characteristic of this oceanographic region. The model, on the contrary, produces yearly averages. We compare the dissolved Al measurements as available from the U.S. JGOFS Arabian Sea program, without averaging and the offset between model results and observations might reflect the discrepancy between a signal influenced by seasonality and the modeled average.

[36] Similarly, a strong seasonality is characteristic of the Southern Ocean and again we compare observations without averaging of data (U.S. JOGFS) to model results. Andersen et al. [1998] predict a higher dust flux to Southern Ocean surface waters and modeled dissolved Al levels show a constant off-set when compared to those predicted from dust input after Mahowald et al. [1999]. The fit between observed and simulated dissolved $\mathrm{Al}$ levels is best for the simulation forced with a dust input following Mahowald et al. [1999] suggesting a better estimation of dust delivery (Figure 10c). A comparison with global aerosol fluxes 
compiled by Duce et al. [1991] confirms our conclusion. The area between $53^{\circ} \mathrm{S} 185^{\circ} \mathrm{E}$ and $62^{\circ} \mathrm{S} 191^{\circ} \mathrm{E}$ lies between the 0.03 and $0.27 \mathrm{mg} / \mathrm{m}^{2} / \mathrm{yr}$ flux isoline, as compared to simulated deliveries ranging between 2.0 and $3.0 \mathrm{mg} / \mathrm{m}^{2} / \mathrm{yr}$ [Andersen et al., 1998], respectively 0.1 to $1.0 \mathrm{mg} / \mathrm{m}^{2} / \mathrm{yr}$ [Mahowald et al., 1999].

[37] In the Central Pacific Ocean, vertical profiles of dissolved $\mathrm{Al}$ (Figure 11) obtained for a dust input after Andersen et al. [1998] exhibit concentrations that are largely overestimated. Too high levels of dissolved Al could reflect an overestimation of dust delivery to the surface ocean. Consistent with this line of evidence, dissolved $\mathrm{Al}$ levels are in the right order of magnitude using the lower dust flux predicted by Mahowald et al. [1999]. Dust delivery to the surface ocean at both sampling sites predicted by Andersen et al. [1998] ranges between 1.0 and 2.0 $\mathrm{mg} / \mathrm{m}^{2} / \mathrm{yr}$. Mahowald et al. [1999] computed a yearly mineral aerosol flux of only 0.1 to $1.0 \mathrm{mg} / \mathrm{m}^{2} / \mathrm{yr}$. These values are in good agreement with estimates by Duce et al. [1991], which are $>0.27 \mathrm{mg} / \mathrm{m}^{2} / \mathrm{yr}$ for the northern station, respectively $<0.27 \mathrm{mg} / \mathrm{m}^{2} / \mathrm{yr}$ for the southern station. Differences between dust fluxes alone can not explain the mismatch between modeled and observed profiles.

[38] The parameterization of scavenging might by invoked as an alternative explanation. The biogeochemical model predicts low levels of opal production (Heinze et al., submitted manuscript, 2002) for the Central Pacific Ocean. The parameterization of scavenging assumes a preferential uptake of dissolved $\mathrm{Al}$ by biogenic siliceous particles. While there is evidence for the preferential scavenging of dissolved Al by diatoms [Dymond et al., 1997], the importance of other carrier phases in situations where diatom production is low cannot be excluded. The resulting underestimation of dissolved $\mathrm{Al}$ removal by reaction with particle surfaces would explain the unrealistic high Al levels throughout the water column.

\section{Conclusion}

[39] This study addresses the suitability of an ocean general circulation model including coupled Al-Si geochemistry as tool for assessing the dust input to the world ocean. Adding the Al geochemistry to the Hamburg Ocean Carbon Cycle Model (HAMOCC2s) and coupling Al-Si geochemical cycles through diatom dynamics, enabled us to duplicate the main characteristics of the world ocean dissolved $\mathrm{Al}$ distribution (order of magnitude of dissolved $\mathrm{Al}$ levels, vertical distribution, between ocean basin fractionation). Model results suggest a solubility of the aluminosilicate fraction of continental aerosols ranging between 1.5 and 3\%. Modeled levels of dissolved Al in surface waters mirror the delivery of dust to the surface ocean. A comparison of two different dust fields [Andersen et al., 1998; Mahowald et al., 1999], yields significant differences in ocean dissolved $\mathrm{Al}$ distributions reflecting the differences between the dust source functions. A comparison between model results and observations allows a differential evaluation of individual source regions and offers an independent check of the underlying parameterization of uplift, transport and deposition of dust as implemented in the Atmospheric General Circulation Model. Assessing the quality of model derived dust input to the surface ocean by means of modeling marine $\mathrm{Al}$ biogeochemistry, contributes to narrow the uncertainties linked to the atmospheric input of continental aerosols. An improved input function of airborne trace elements, as for example $\mathrm{Fe}$, is an important step toward correctly assessing the influence of dust delivery on surface ocean chemistry in general, and on regional surface ocean fertility in particular.

[40] Acknowledgments. The first author acknowledges the hospitality of the Max Planck Institute of Meteorology, Hamburg, and access to the computing facilities of the Deutsches Klima Rechen Zentrum (DKRZ). Partial funding was provided by the European Commission through grant MA3-CT97-0141. This is contribution 0796 of the Laboratoire des Sciences du Climat et de l'Environnement (LSCE).

\section{References}

Andersen, K. K., A. Armengaud, and C. Genthon, Atmospheric dust under glacial and interglacial conditions, Geophys. Res. Lett., 25, 2281-2284, 1998.

Broecker, W. S., and G. M. Henderson, The sequence of events surrounding Termination II and their implications for the cause of glacial-interglacial $\mathrm{CO}_{2}$ changes, Paleoceanography, 13, 352-364, 1998.

Chester, R., K. J. T. Murphy, F. J. Lin, A. S. Berry, G. A. Bradshaw, and P. A. Corcoran, Factors controlling the solubilities of trace metals from non-remote aerosols deposited to the sea surface by dry deposition mode, Mar. Chem., 42, 107-126, 1993.

Chou, L., and R. Wollast, Biogeochemical behavior and mass balance of dissolved aluminum in the western Mediterranean Sea, Deep Sea Res., Part II, 44, 741-768, 1997.

De Angelis, M., N. I. Barkov, and V. N. Petrov, Aerosols concentrations over the last climatic cycle (160 yr) from an Antarctic ice core, Nature, $325,318-321,1987$

Duce, R. A., Sources, distributions, and fluxes of mineral aerosols and their relationship to climate, in Aerosols Forcing of Climate, edited by R. J. Charlson and J. Heintzenberg, pp. 43-72, John Wiley, New York, 1994.

Duce, R. A., et al., The atmospheric input of trace species to the world ocean, Global Biogeochem. Cycles, 5, 193-259, 1991.

Dymond, J., R. Collier, J. McManus, S. Honjo, and S. Manganini, Can the aluminum and titanium contents of ocean sediments be used to determine the paleoproductivity of the oceans?, Paleoceanography, 12, 586-593, 1997.

Gehlen, M., L. Beck, G. Calas, A.-M. Flank, J. A. van Bennekom, and J. E. E. van Beusekom, Unraveling the atomic structure of biogenic silica: Evidence of the structural association of $\mathrm{Al}$ and $\mathrm{Si}$ in diatom frustules, Geochim. Cosmochim. Acta, 66, 1601-1609, 2002.

Heinze, C., Assessing the importance of the Southern Ocean for natural atmospheric $\mathrm{pCO}_{2}$ variations with a global biogeochemical general circulation model, Deep Sea Res., 49, 3105-3125, 2002.

Heinze, C., and E. Maier-Reimer, The Hamburg Oceanic Carbon Cycle Circulation Model Version "HAMOCC2s" for long time integrations, Tech. Rep. 20, 71 pp., Deutsches Klimarechenzentrum (German Clim. Comput. Cent.), Hamburg, Germany, 1999.

Heinze, C., E. Maier-Reimer, and K. Winn, Glacial $\mathrm{pCO}_{2}$ reduction by the world ocean: Experiments with the Hamburg carbon cycle model, Paleoceanography, 6, 395-430, 1991.

Heinze, C., E. Maier-Reimer, A. M. E. Winguth, and D. Archer, A global oceanic sediment model for long-term climate studies, Global Biogeochem. Cycles, 13, 221-250, 1999.

Helmers, E., and M. Rutgers van der Loeff, Lead and aluminum in Atlantic surface waters $\left(50^{\circ} \mathrm{N}\right.$ to $\left.50^{\circ} \mathrm{S}\right)$ reflecting anthropogenic and natural sources in the eolian transport, J. Geophys. Res., 98, 20,261-20,274, 1993.

Hydes, D. J., Aluminium in seawater: Control by inorganic processes, Science, 205, 1260-1262, 1979.

Hydes, D. J., Seasonal variations in dissolved aluminum concentrations in coastal waters and biological limitation of the export of the riverine input of aluminum to the deep sea, Cont. Shelf Res., 9, 919-929, 1989.

Hydes, D. J., and P. S. Liss, Fluorimetric method for the determination of low concentrations of dissolved aluminium in natural waters, Analyst, 101, 922-931, 1976.

Jickells, T. D., T. Church, A. Veron, and R. Arimoto, Atmospheric inputs of manganese and aluminum to the Sargasso Sea and their relation to surface water concentrations, Mar. Chem., 46, 283-292, 1994. 
Jouzel, J., et al., Extending the Vostok ice-core record of paleo-climate to the penultimate glacial period, Nature, 364, 407-412, 1993.

Kremling, K., The distribution of cadmium, copper, nickel, manganese, and aluminium in surface waters of the open Atlantic and European shelf area, Deep Sea Res., 32, 531-555, 1985.

Li, Y.-H., Distribution patterns of the elements in the ocean: A synthesis, Geochim. Cosmochim. Acta, 55, 3223-3240, 1991.

Mackenzie, F. T., and R. M. Garrels, Chemical mass balance between rivers and oceans, Am. J. Sci., 264, 507-525, 1966.

Mackenzie, F. T., M. Stoffyn, and R. Wollast, Aluminium in seawater: Control by biological activity, Science, 199, 680-682, 1978.

Mahowald, N., K. Kohfeld, M. Hansson, Y. Balkansi, S. P. Harrison, I. C. Prentice, M. Schulz, and H. Rohde, Dust sources and deposition during the Last Glacial Maximum and current climate: A comparison of model results with paleodata from ice cores and marine sediments, J. Geophys. Res., 104, 15,895-15,916, 1999.

Maier-Reimer, E., Geochemical cycles in an ocean general circulation model: Preindustrial tracer distributions, Global Biogeochem. Cycles, 7, 645677, 1993.

Maring, H. B., and R. A. Duce, The impact of atmospheric aerosols on trace metal chemistry in open ocean surface seawater, 1, Aluminum, Earth Planet. Sci. Lett., 84, 381-392, 1987.

Marticorena, B., and G. Bergametti, Two-year simulations of seasonal and interannual changes of the Saharan dust emissions, Geophys. Res. Lett., 90, 16,415-16,430, 1995.

Martin, H. B., and S. E. Fitzwater, Iron deficiency limits phytoplankton growth in the north-east subarctic Pacific, Nature, 331, 341-343, 1988.

Measures, C. I., The distribution of $\mathrm{Al}$ in the IOC stations of the South and central Atlantic, Mar. Chem., 49, 267-281, 1995.

Measures, C. I., and E. T. Brown, Estimating dust input to the Atlantic Ocean using surface water Al concentrations, in The Impact of Desert Dust Across the Mediterranean, edited by S. Guerzoni and R. Chester, pp. 301-311, Kluwer Acad., Norwell, Mass., 1996.

Measures, C. I., and J. M. Edmond, Aluminium as a tracer of the deep outflow from the Mediterranean, J. Geophys. Res., 93, 591-595, 1988.

Measures, C. I., and J. M. Edmond, Shipboard determination of aluminum in seawater at the nanomolar level by electron capture detection gas chromatography, Anal. Chem., 61, 544-547, 1989.

Measures, C. I., and J. M. Edmond, Aluminium in the south Atlantic: Steady state distribution of a short residence time element, J. Geophys. Res., 95, 5331-5340, 1990.

Measures, C. I., and J. M. Edmond, The distribution of aluminium in the Greenland Sea and its relationship to ventilation processes, J. Geophys. Res., 97, 17,787-17,800, 1992.

Measures, C. I., and S. Vink, On the use of dissolved aluminum in surface waters to estimate dust deposition to the ocean, Global Biogeochem. Cycles, 14, 317-327, 2000.

Measures, C. I., B. Grant, M. Khadem, D. S. Lee, and J. M. Edmond, Distribution of $\mathrm{Be}, \mathrm{Al}, \mathrm{Se}$ and $\mathrm{Bi}$ in the surface waters of the Western North Atlantic and Caribbean, Earth Planet. Sci. Lett., 71, 1-12, 1984.

Measures, C. I., J. M. Edmond, and T. D. Jickells, Aluminum in the north west Atlantic, Geochim. Cosmochim. Acta, 50, 1423-1429, 1986.

Moran, S. B., and R. M. Moore, Evidence from mesocosm studies for biological removal of dissolved aluminium from sea water, Nature, 335, 706-708, 1988.

Moran, S. B., and R. M. Moore, The distribution of colloidal aluminum and organic carbon in coastal and open ocean waters off Nova Scotia, Geochim. Cosmochim. Acta, 53, 2519-2527, 1989.

Moran, S. B., and R. M. Moore, Kinetics of the removal of dissolved aluminum by diatoms in seawater: A comparison with thorium, Geochim. Cosmochim. Acta, 56, 3365-3374, 1992.
Orians, K. J., and K. W. Bruland, Dissolved aluminium in the central North Pacific, Nature, 316, 427-429, 1985.

Orians, K. J., and K. W. Bruland, The biogeochemistry of aluminum in the Pacific Ocean, Earth Planet. Sci. Lett., 78, 397-410, 1986.

Parsons, T. R., and M. Takahashi, Biological Oceanographic Processes, 186 pp., Pergamon, New York, 1973.

Petit, J. R., L. Mounier, J. Jouel, Y. S. Korotkevich, V. I. Kotlyakov, and C. Lorius, Paleoclimatological and chronological implications of the Vostok core dust record, Nature, 343, 56-58, 1990.

Prospero, J. M., R. T Nees, and M. Uematsu, Deposition rate of particulate and dissolved aluminum derived from Saharan dust in precipitation at Miami, Florida, J. Geophys. Res., 92, 14,723-17,731, 1987.

Rea, D. K., The paleoclimatic record provided by eolian deposition in the deep sea: The geologic history of wind, Rev. Geophys., 32, 159-195, 1994.

Resing, J., and C. I. Measures, Fluorimetric determination of $\mathrm{Al}$ in seawater by FIA with in-line preconcentration, Anal. Chem., 66, 4105-4111, 1994.

Stoffyn, M., Biological control of dissolved aluminium in seawater: Experimental evidence, Science, 203, 651-653, 1979.

Taylor, S. R., Abundance of chemical elements in the continental crust: A new table, Geochim. Cosmochim. Acta, 28, 1273-1285, 1964.

Tegen, I., and I. Fung, Modeling of mineral dust in the atmosphere: Sources, transport and optical thickness, J. Geophys. Res., 99, 22,89722,914, 1994

Turner, D. R., M. Whitfield, and A. G. Dickson, The equilibrium speciation of dissolved components in freshwater and seawater at $25^{\circ} \mathrm{C}$ and $1 \mathrm{~atm}$ pressure, Geochim. Cosmochim. Acta, 45, 855-881, 1981.

van Beusekom, J. E. E., Distribution of dissolved aluminium in surface waters of the North Sea: Influence of biological processes, in Biogeochemistry and Distribution of Suspended Matter in the North Sea and Implications to Fisheries Biology, edited by S. Kempe et al., Mitt. Geol. Palaeontol. Inst. Univ. Hamburg, 65, 137-151, 1988.

Vink, S., and C. I. Measures, The role of dust deposition in determining surface water distributions of $\mathrm{Al}$ and $\mathrm{Fe}$ in the South West Atlantic, Deep Sea Res., Part II, 48, 2787-2809, 2001.

Wedepohl, K. H., The composition of the continental crust, Geochim. Cosmochim. Acta, 59, 1217-1232, 1995.

Winguth, A. M. E., Assimilation von delta113C-Daten aus marinen Sedimentbohrkernen in das LSG zur Rekonstruktion der Ozeanzirkulation während des letzten glazialen Maximums, Ph.D. thesis, 155 pp., MaxPlanck-Inst. für Meteorol., Hamburg, Germany, 1997.

Winguth, A. M. E., D. Archer, J. C. Duplessy, E. Maier-Reimer, and U. Mikolajewicz, Sensitivity of paleonutrient tracer distributions and deep sea circulation to glacial boundary conditions, Paleoceanography, 14, 304-323, 1999.

M. Gehlen, Laboratoire des Sciences du Climat et de l'Environnement (LSCE), UMR CEA-CNRS, Orme des Merisiers Bât. 709, CE Saclay, F-91191 Gif-sur-Yvette, France. (gehlen@lsce.saclay.cea.fr)

C. Heinze, National Environmental Research Institute (NERI), Frederiksborgvej 399, PO Box 358, DK-4000 Roskilde, Denmark. (che@dmu.dk)

C. I. Measures, Department of Oceanography, University of Hawaii, 1000 Pope Road, Honolulu, HI 96822, USA. (chrism@soest.hawaii.edu)

E. Maier-Reimer, Max Planck Institut of Meteorology, Department of Atmospheric Chemistry and Climate Dynamics, Bundesstrasse 55, D20146 Hamburg, Germany. (maier-reimer@dkrz.de) 
(a) dust deposition $[\mathrm{mg} /(\mathrm{m} 2$ day $)]$

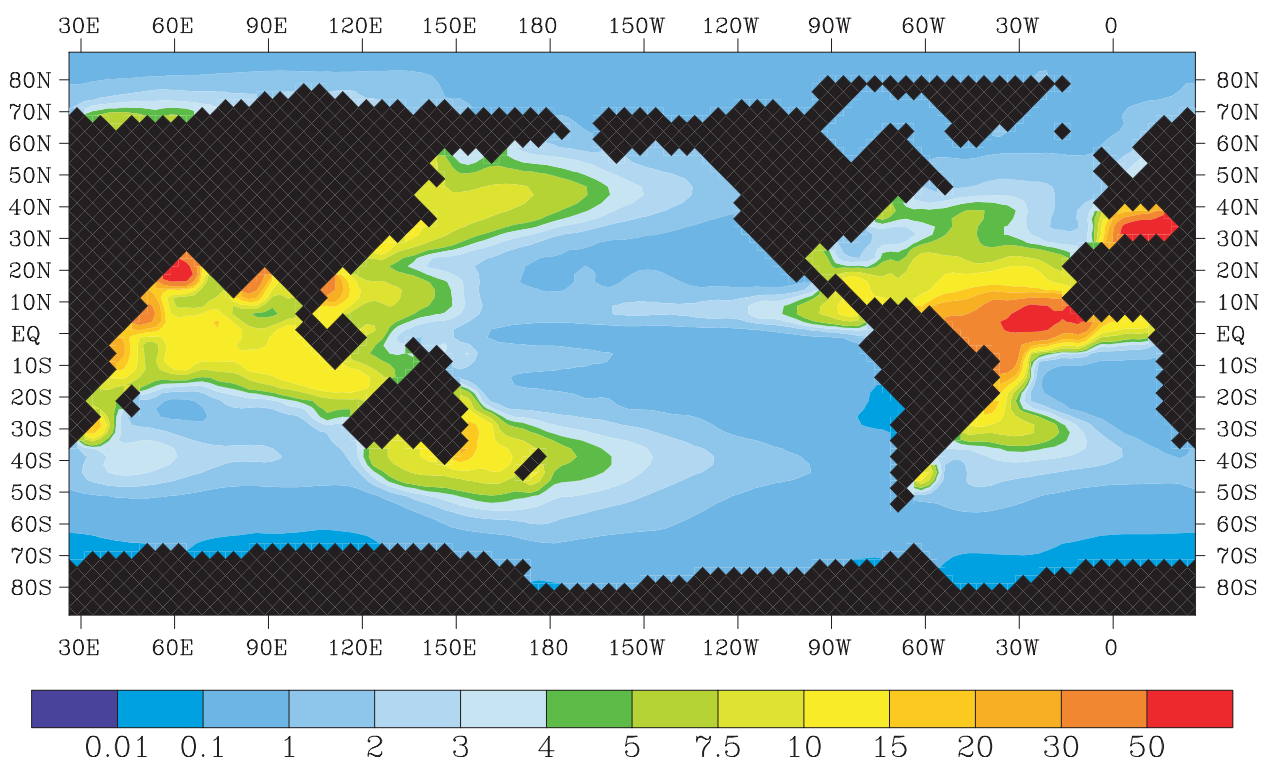

(b) dust deposition $[\mathrm{mg} /(\mathrm{m} 2$ day $)]$

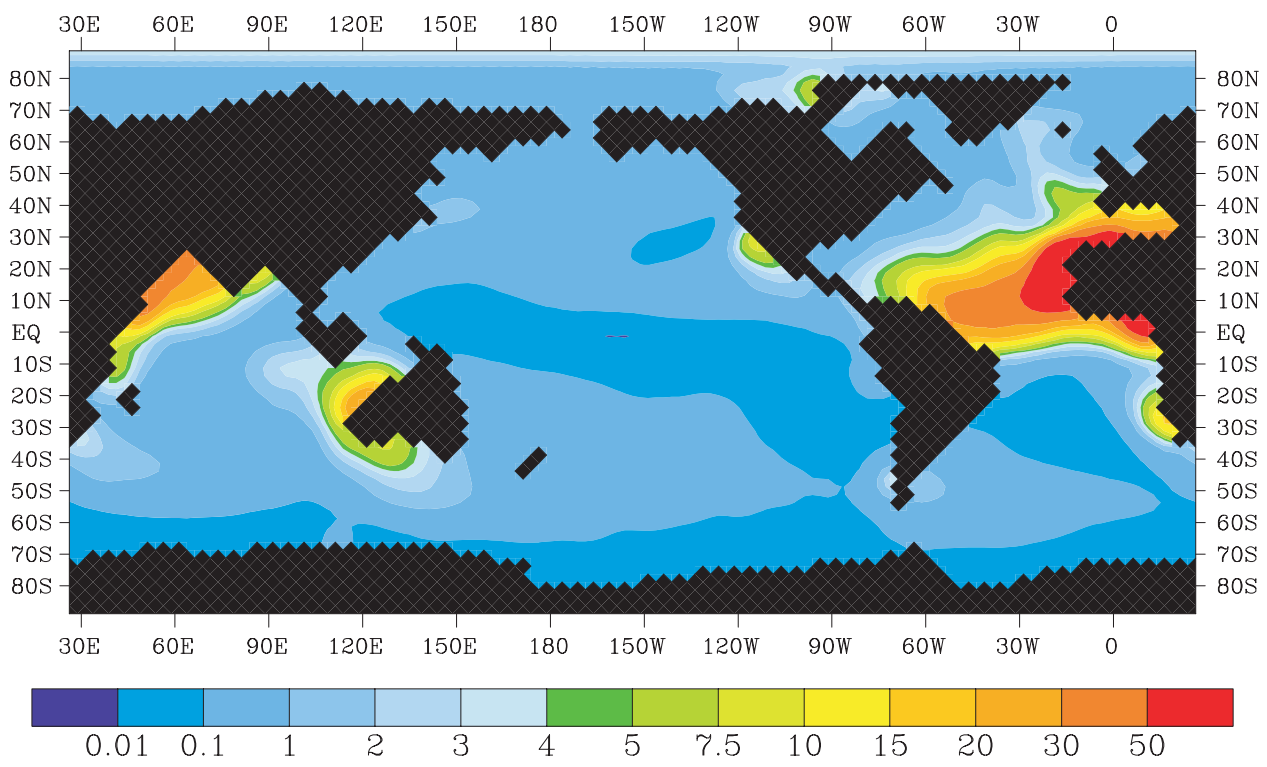

Figure 1. Annually averaged dust deposition (mg/m²/d) after (a) Andersen et al. [1998] and (b) Mahowald et al. [1990]. 


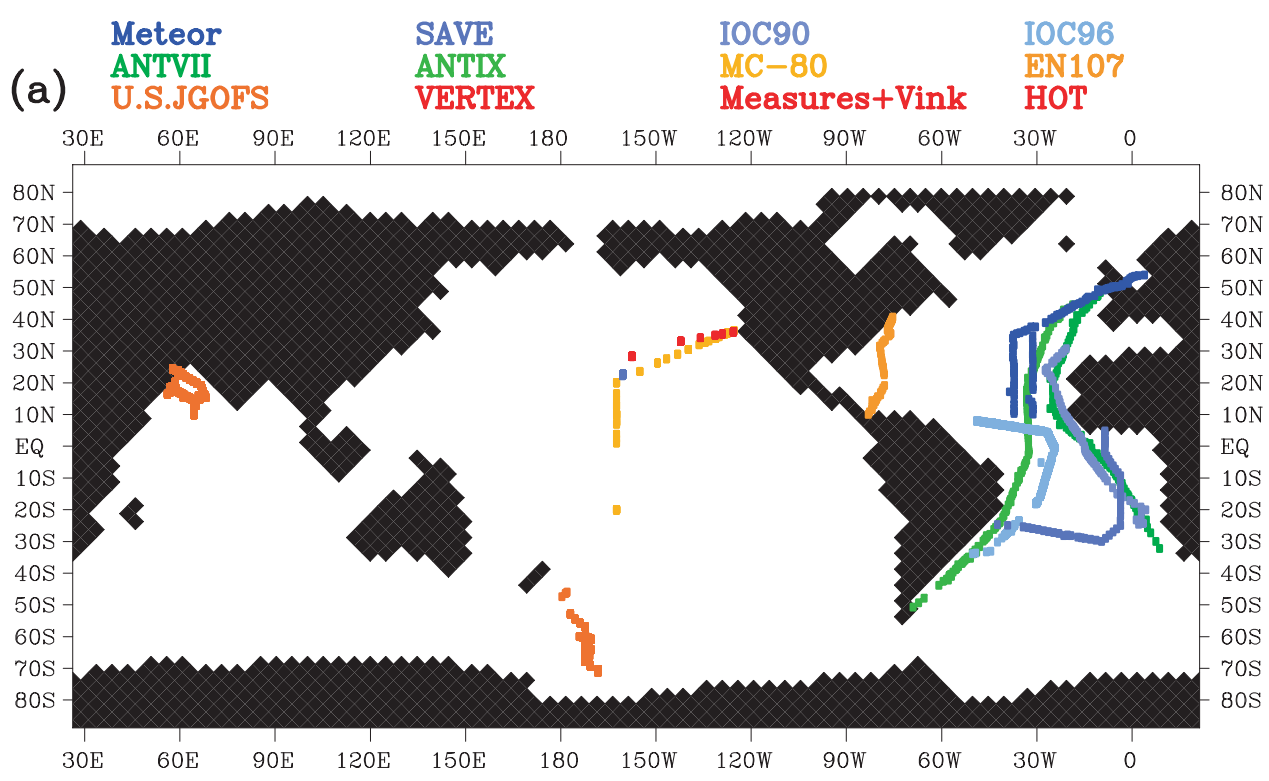

(b) dissolved Al [nmol/l]

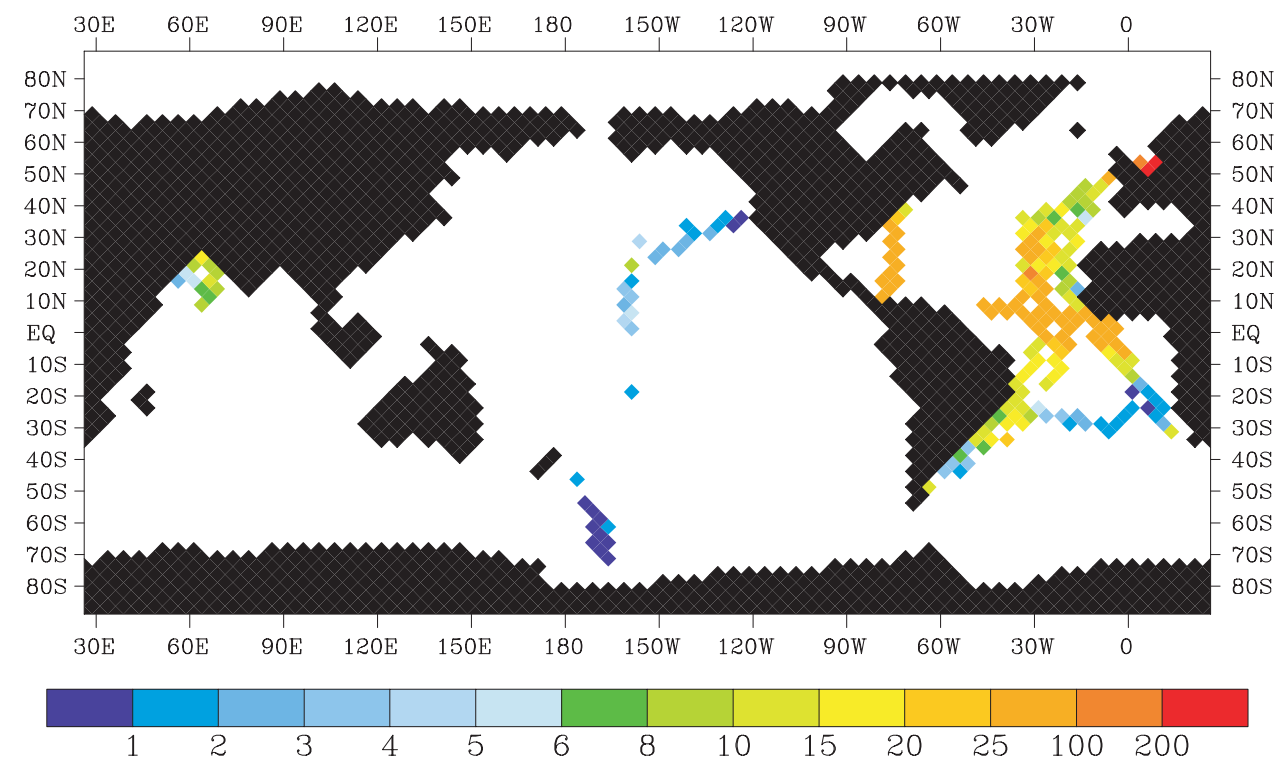

Figure 2. Location of dissolved Al measurements compiled from cruises listed in Table 2. (a) Individual cruise tracks and (b) corresponding measured surface ocean dissolved $\mathrm{Al}$ concentrations as averages over a model grid cell $\left(3.5^{\circ} \times 3.5^{\circ}\right)$. 


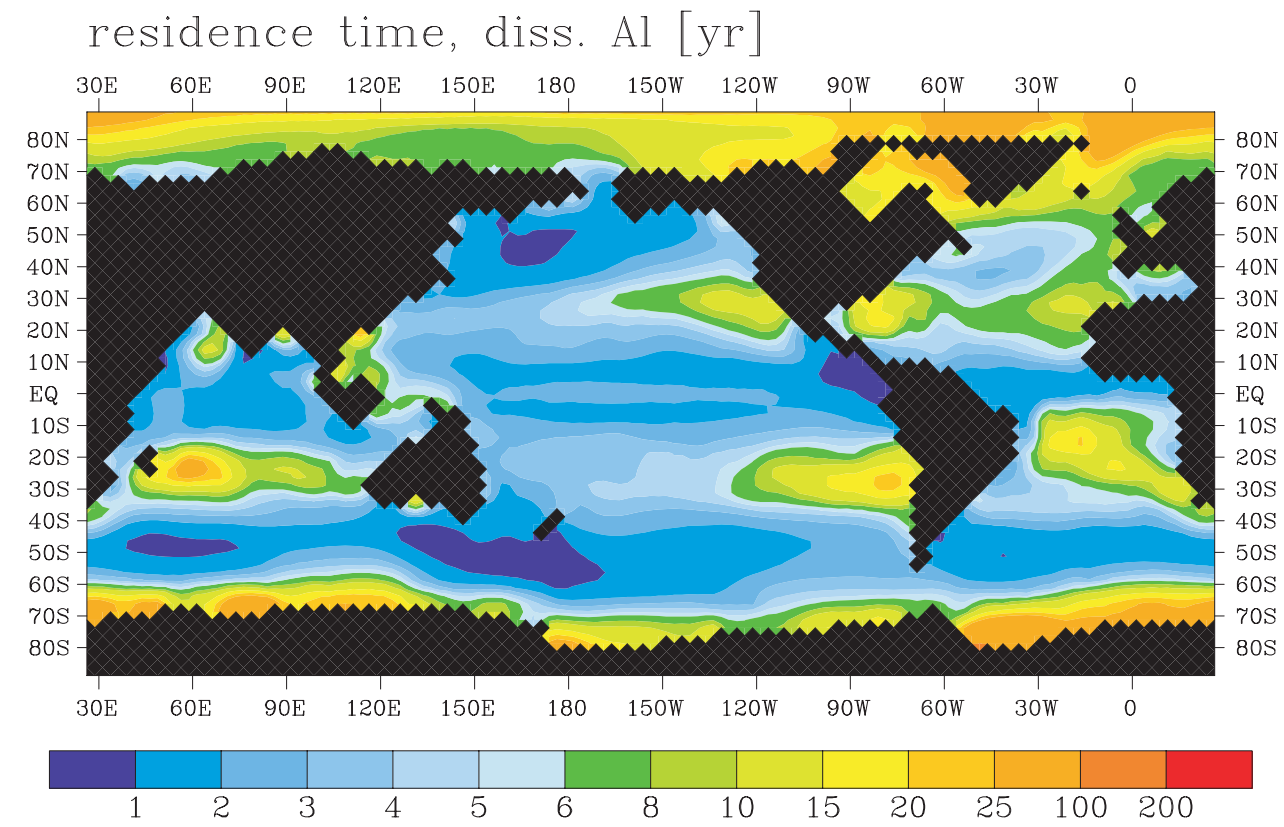

Figure 5. Residence times for dissolved $\mathrm{Al}$ in surface waters computed for the standard run. Dust input after Andersen et al. [1998]. Solubility of aluminosilicate fraction $=3 \%$. 